\title{
A NEW (?) FRAMEWORK (?) ON DIGITALIZATION IN EUROPEAN (?) COMPANY (?) LAW?
}

\author{
Alessio Bartolacelli *
}

\begin{abstract}
In this paper, I consider the digital tools present in the European Company law currently in force, and those that have been proposed in several occasions and by different bodies during the last fifteen years. I will focus in particular on the European Commission's Proposal issued on April 25 ${ }^{\text {th }}, 2018$, showing that it does not provide a comprehensive and innovative framework on digitalization in Company Law. On the contrary, its main purpose is to suggest the introduction of a harmonized system of online registration for companies throughout Europe, directly descending from the last available version of the repealed Proposal for the amendment of Single-Member companies directive. Such a procedure, nonetheless, is dealing just partially with Company Law, as it involves a public procedure, usually part of administrative law, and, even more meaningfully, it needs to develop a role for notaries where the intervention of such subjects is required by domestic law.

Furthermore, besides highlighting the momentous role the domestic registers and the business registers' interconnection system have achieved in the European Company Law, I will discuss some points in the latest Proposal and its Annex that seem to need a reconsideration.
\end{abstract}

KEYWORDS: Digitalization, Company Law, Company's Registration, Online Filing, Disqualified Directors, Business Registers' Interconnection System, ICLEG Group, Company's Website, Notaries

Senior Lecturer of Business Law at University of Macerata - Department of Law; alessio. bartolacelli@unimc.it 


\section{INTRODUCTION}

When dealing with the issue of digitalization in European Company Law, one could be tempted to consider only the latest "Digital Company Law Package" issued by European Commission on April 25 ${ }^{\text {th }}, 2018 .{ }^{1}$ It must nonetheless be noted that digitalization is an issue rather widely considered by European institutions at least in the last fifteen years. Many hints regarding an interest in the subject were present already in the so-called "Winter report", as of 2002, when considering a few domestic experiences. ${ }^{2}$ Similarly, in the Action Plan consequently developed by the Commission in $2003^{3}$ - and to a much lower extent in that issued in 2012, too ${ }^{4}$ - many digital issues were present as well. And, even if it has not a direct link with Company Law, we must furthermore point out that the European Commission developed and launched a Digital Agenda for Europe ${ }^{5}$ (and very recently even a Digital Agenda for Western Balkans $^{6}$ ) as a part of the Single Digital Market.

For this reason, in this article I will consider first the "theoretical sources" of the digitalization, by examining the just mentioned documents, focusing in particular on the experts' reports and their fallouts in official European documents.

\footnotetext{
1 Proposal for a Directive of the European Parliament and of the Council amending Directive (EU) 2017/1132 as regards the use of digital tools and processes in company law, of 25 April 2018, COM (2018) 239 final, [https://eur-lex.europa.eu/legal-content/EN/TXT/PD$\mathrm{F} /$ ?uri=CELEX:52018PC0239\&from=EN], accessed on 06/08/2018.
}

2 Report of the high level group of company law experts on a modern regulatory framework for company law in Europe, of 4 November 2002, [http://ec.europa.eu/internal_market/company/docs/modern/report_en.pdf], accessed on 06/08/2018. In particular, the German Corporate Governance Codex was considered in the Consultative Document, as it is referred at p. 142.

3 Communication from the Commission to the Council and the European Parliament: Modernising Company Law and Enhancing Corporate Governance in the European Union - A Plan to move Forward, of 21 May 2003, COM (2003) 284 final, [https://eur-lex.europa.eu/legal-content/EN/TXT/PDF/?uri=CELEX:52003DC0284\&from=EN], accessed on 06/08/2018.

4 Communication from the Commission to the European Parliament, the Council, the European Economic and Social Committee and the Committee of the Regions: Action Plan: European company law and corporate governance - a modern legal framework for more engaged shareholders and sustainable companies, of 12 December 2012, COM (2012) 740 final, [https:// eur-lex.europa.eu/legal-content/EN/TXT/PDF/?uri=CELEX:52012DC0740\&from=EN], accessed on 06/08/2018.

5 Communication from the Commission to the European Parliament, the Council, the European Economic and Social Committee and the Committee of the Regions: A Digital Agenda for Europe, of 26 August 2010, COM (2010) 245 final/2, [https://eur-lex.europa.eu/legal-content/EN/TXT/PDF/?uri=CELEX:52010DC0245\&from=FRF], accessed on 06/08/2018.

6 Statement of Support: the Digital Agenda for the Western Balkans, of 17 May 2018, [https://ec.europa.eu/commission/sites/beta-political/files/statement-support-digital-agenda-western-balkans_en.pdf], accessed on 06/08/2018. 
I will then move to the analysis of the "status quo", i.e. those profiles of digitalization that can already be found out in the European Law currently in force, starting from the Codified Directive 2017/1132/EU, but also looking at the directives on shareholders' rights and accounts in particular.

The next step will be the consideration of the draft legislation currently under discussion at an advanced stage by European institutions in the area of digitalization, mainly the Single Digital Gateway proposal, focusing on the impact of such proposal on Company Law.

Finally, the analysis will move to the newest Commission's comprehensive draft proposal of April 2018, highlighting in particular the proposed process of online company's registration, discussing its origins from the withdrawn SUP directive draft proposal, ${ }^{7}$ and its strict dependence from the so-called e-IDAS Regulation, ${ }^{8}$ concerning the identification of persons throughout the Union, and its full implementation as of September 29 2018.

\section{THE THEORETICAL FRAMEWORK OF DIGITALIZATION IN EUROPEAN COMPANY LAW}

\subsection{THE WINTER REPORT (2002)}

If it is true that European Company Law's golden era has probably ended in the early Nineties of the last century, ${ }^{9}$ since the dawn of the years 2000 the attention of European institutions focused on several digital profiles of Company Law. This happened not only because of the technological revolution taking place in those years by itself, but due to the digital attitude some Member States had already started to develop in their domestic law.

\footnotetext{
7 Proposal for a Directive of the European Parliament and of the Council on single-member private limited companies, of 9 April 2014, COM (2'14) 212 final, [https://eur-lex.europa.eu/legal-content/EN/TXT/PDF/?uri=CELEX:52014PC0212\&from=EN], accessed on 06/08/2018, hereinafter: also "SUP proposal, original version".

In this essay I will also refer to a later version of the same proposal, coming from the General approach issued by the Council of the European Union in its meeting of May $29^{\text {th }}, 2015$, [http:// data.consilium.europa.eu/doc/document/ST-9050-2015-INIT/en/pdf], accessed on 06/08/2018, hereinafter also "SUP proposal, G.A. version".

8 Regulation (EU) No 910/2014 of the European Parliament and of the Council of 23 July 2014 on electronic identification and trust services for electronic transactions in the internal market and repealing Directive 1999/93/EC, (OJ L 257, 28/8/2014).

9 Rondinelli, M.: L'armonizzazione nel diritto delle società: evoluzioni e prospettive, in: Pederzini, E. (ed.): Percorsi di diritto societario europeo, Turin, 2016, p. 53 ss.
} 
Probably looking at the difficulties arisen in the development of new political initiatives in the area of Company Law, since the beginning of the new century the European institutions decided to create many subsequent commissions or steering groups. They have been formed by high level experts coming from many Member States' universities and research institutions, in order to try to develop a technical "to-do agenda" in the field, elaborated by such expert, with scientific criteria. The very first of those steering groups was the "High Level Group of Company Law Experts", operating mainly between 2001 and 2002, and chaired by Dutch professor Jaap Winter, hence the common definition of the group as "the Winter Group".

In November 2002, the Group issued a "Report [...] on a modern regulatory framework for company law in Europe", commonly known as "the Winter Report", intended to be a milestone for the subsequent proposals in the area of Company Law developed by the European Commission. The report was not, by itself, an official European document, but its content served at large for the elaboration of the Action Plans in the area during the following years, in particular the 2003 one.

The issue of digitalization was not a core point of the report; it was nonetheless present regarding a few subjects, in particular dealing with the participation of the company's members to the company's activities and to the meetings in particular, highlighting the possible use of ICT for pre-meeting information, participation in the meeting, and voting rights. ${ }^{10}$ In general, the Report recognized that "Modern information and communication technology has a profound impact on our society. Law should adapt to this in that, on the one hand, it should ensure that legal norms and values are also applied in a digital or virtual environment, and, on the other hand, it should facilitate exploitation of the new possibilities which modern technology offers". ${ }^{11}$

Nevertheless, this does not mean, by itself, that specific steps had to be taken in the field by the European institutions: the Report distinguishes between "form", "time", "place" and "function" related issues, the modern technologies were likely to have an impact on. The attitude of the Group on that was that there was no need of a European initiative regarding the chapters "form" - as Member States were already acting by themselves on that - and "time" - due to the fact that "law should not force citizens to act quicker now that modern technology allows speedier actions and decisions. Law may even wish to protect citizens against overhasty actions and decisions that are prompted by fast-

\footnotetext{
10 On members' information, p. 49; voting right, p. 10; participation to the meeting, p. 8, 52 e 74.

11 Page 36 of the Report. The entire paragraph is of the utmost importance to the extent of this analysis.
} 
er communication methods"12; while, on the contrary, it was part of a priority initiative to consider the chapters "place"13 and "function" - i.e. the one related with participation of members in a company's life based on the use of ICT. At the same time, the Report stresses that a great role for modern technologies could have been played in the filing and disclosure phase, which is properly what has been happening with the registers' interconnection system currently in force since July $2017 .{ }^{14}$

In any case, it seems that the continuous attention the Report devotes to the role of modern technology in companies with reference to shareholders' information and exercise of rights can be held as the inspiration of many of the provisions contained in the "shareholders' rights Directive" either in its original ${ }^{15}$ and amended ${ }^{16}$ versions. ${ }^{17}$ This, naturally, leads to more general remarks on the foreseeable role and way of actual development of the shareholders' meeting as we usually intend it, as modern technologies could easily lead to fully notin-presence meetings. ${ }^{18}$

\section{Page 37 of the Report.}

13 Having the strong transnational character now present in the Proposal for a Directive of the European Parliament and of the Council amending Directive (EU) 2017/1132 as regards cross-border conversions, mergers and divisions, of 25 April 2018, COM (2018) 241 final, [https://eur-lex.europa.eu/legal-content/EN/TXT/PDF/?uri=CELEX:52018PC0241\&from=EN], accessed on 06/08/2018.

In this draft too many references to digitalisation are present as well, with the same leading lines we can find in the Digitalisation Proposal. In particular see proposed arts. 86e.3, 86f.3, 86h.2, $.3(\mathrm{~d})$, and $.4,86 \mathrm{~m} .3,86 \mathrm{o} .2,86 \mathrm{p} .3$, and 86q.2 and .3 for conversions; proposed arts. 123.1, .2, and $.4,124.3,124 \mathrm{a} .3,126 \mathrm{a} .3,127.1$ and .2 , and 128.3 and .4 for amendments to cross-border mergers; proposed arts. 160g.3, 160h.3, 160j.1, .2, .3(d), and .4, 1601.3, 160o.3, 160q.2, 160r.3, and $160 \mathrm{~s} .2$ and .3 for divisions.

14 We are going to discuss this issue more in depth in the next chapter 3, but see p. 39 of the Report.

15 Directive 2007/36/EC of the European Parliament and of the Council of 11 July 2007 on the exercise of certain rights of shareholders in listed companies, (OJ L 184, 14/7/2007).

16 Directive (EU) 2017/828 of the European Parliament and of the Council of 17 May 2017 amending Directive 2007/36/EC as regards the encouragement of long-term shareholder engagement (Text with EEA relevance), (OJ L 132, 20/5/2017).

17 A balance is specifically considered as far as the right to ask questions is concerned, in order to avoid that "The company could virtually be flooded with questions and proposals" ( $\mathrm{p}$. 51). With this regard, a specific instrument by the EU was hot held necessary by respondent stakeholders: "The rights to ask questions and table resolutions are often difficult to exercise, but responses to the consultation did not call for mandatory provisions at EU level in this area. In practice, the exercise of these important rights may be facilitated by modern technology, but companies should be able to take measures to keep the whole process manageable", p. 7.

18 "The development of technological means through which shareholders can communicate with management and each other and can take decisions without actually meeting, and the 
As for the listed companies in particular, the information to be provided in the company's website is highly stressed, ${ }^{19}$ along with the links to be maintained with public registers and authorities. However, the Winter Group points out that from the consultation they carried out with stakeholders, a trend emerged that a simply enabling provision would have been preferable instead of a compulsory one regarding the use of modern technologies by listed companies. ${ }^{20}$

\subsection{THE 2003 ACTION PLAN}

As it was easily expectable, the Winter Report was used by European Commission in order to develop an Action Plan in the field of modernization of European - and by this means, of Member States' too - Company Law; the Action plan was issued in May 2003. ${ }^{21}$ The issue of modern technologies, tracing back to the title of the Communication focused on Company Law modernization, is one of the core parts of the Plan, even if not all the suggestions and remarks on the issue present in the Winter Report are contained in it too.

The approach the Commission had in the 2003 Action Plan is the acknowledgment of the modern technologies and the fact that they were "affecting the way company information is stored and disseminated, as well as the way corporate life is conducted (e.g. virtual general meetings, video-link board meetings, exercise of cross-border voting rights)". ${ }^{22}$ From this starting point, the Communication adopts the balanced solution the Winter Group advocated for too: general encouragement for the use of modern technologies by the companies

facilitating of these developments in law, inevitably lead to the question whether a physical meeting of shareholders still plays any useful role", p. 53.

19 See for instance p. 6.

20 "In our Consultative Document, we asked whether listed companies should not only be entitled to use modern technology as suggested above (i.e. that the use should be permitted by Member States' Company Laws - the "enabling" approach), but should be compelled to do so. Many respondents have expressed the view that use of modern technology should be a matter for the companies and their shareholders to decide and not for the Member States or the EU to determine", p. 49. Again, more in general, "Many respondents to our Consultative Document stressed that, at the current stage of development and availability of new technologies, the use of modern technology should not be imposed but should merely be facilitated. We agree that an appropriate balance must be struck", p. 28.

21 See above, ref. 3.

222003 Action Plan, p. 7, where in footnotes there is a cross reference to a Proposal for amendments to the First Company Law Directive, issued in June 2002, introducing modern technologies in the trade registers. It is possible to see in such proposal the seed of the Business Registers' Interconnection System eventually approved by the Parliament and the Council and now part of the codified Directive (EU) 2017/1132. 
in their relationships with members and third parties; mandatory provisions regarding the use of such technologies where "the protection of shareholders and third parties [makes] it necessary to compel companies" to use them. ${ }^{23}$ In any case, a general imposition for companies for a systematic use of modern technologies towards all members and third parties was still deemed as premature.

As for the actual solutions proposed, the 2003 Action Plan deals with the issue of shareholders' rights, mainly in listed companies. In them, the pre-meeting information could be provided for by means of "electronic facilities", ${ }^{24}$ being thus the first step for further measures in the field of shareholders' information. Some additional issues, for instance on the right to ask questions, vote in absentia and taking part to the meetings by means of electronic technologies were to be dealt with by means of a then forthcoming Directive. ${ }^{25}$

\subsection{THE 2010 DIGITAL AGENDA FOR EUROPE}

In 2010 the Commission took entirely acknowledgment of the importance of digital issues for the contemporary Company Law by issuing the Communication: "A Digital Agenda for Europe", drafting a complete line of intervention of European institution in the coming years. Such document is not focused

23 Citation from the 2003 Action Plan, p. 8 seq., where the mentioned compulsory rule seems to be applicable mainly to listed and open companies, sounding a solution similar to the one later adopted in the shareholders' right Directive.

242003 Action Plan, p. 13.

25 Properly the Shareholders' rights Directive, which finally dealt also with pre-meeting information, where in the Action Plan such issue was said to be regulated by the Transparency Directive (Directive 2004/109/EC, of 15 December 2004, (OJ L 390, 31/12/2004), actually containing just partial rules about that. This Directive, aiming at harmonising "transparency requirements in relation to information about issuers whose securities are admitted to trading on a regulated market", lays down some digitally-related provisions with reference to listed companies. Among them, we can find: the encouragement to the Member States' SUPervisory authorities "to formulate guidelines for setting up electronic networks" (Whereas 26; article 22); rules on instructions regarding the exercise of voting rights to be $S U P$ plied to the shareholders also "by electronic means" (articles 9.4; 11.5); the provision regarding electronic proxy forms (articles 17.2[b]; 18.2[b]); conveying of information to shareholders via electronic means, upon a general meeting's decision and the shareholders' consent, on an equal treatment basis (articles 17.3; 18.4).

Besides that, the possibility to file information to the national competent authority via electronic means is affirmed (article 19.4[a]), while in general "electronic mean" is defined - rather generically - as: "means of electronic equipment for the processing (including digital compression), storage and transmission of data, employing wires, radio, optical technologies, or any other electromagnetic means" (article 2.1[1]). This means that, for instance, a normal e-mail is already fulfilling the requirements for being an electronic mean for the Transparency Directive. 
on Company, nor Business, Law in particular, but many of the issues it deals with are closely related to this sector. In particular, the very first area of action mentioned in the document is the enhancement of a "vibrant Single Digital market", which is naturally linked to the entire field of Business Law. However, in such Communication no anticipation of foreseeable actual rules in the field of Company Law is present, while in the broader area of Business Law there were: the idea of "pan-European licensing" and other copyright related issues; the enhancement of electronic payments and eInvoicing; ${ }^{26}$ the focus on online shopping as a consequence of an higher degree of trust in online shops to be achieved by European citizens; telecommunication services. ${ }^{27}$

Anyway, with reference to Enterprise Law, an obiter in the Communication leads to a subject we are going to analyze in depth in a while. When dealing with eGovernment, it is said that "Member Stated should [...] agree by 2011 on a common list of key cross-border public services that correspond to well defined needs - enabling entrepreneurs to set up and run a business anywhere in Europe independently of their original location, and allowing citizens to study, work, reside and retire anywhere in the European Union. These key services should be available online by $2015 " .{ }^{28}$ This means that, in the original idea of the Commission, the possibility for the creation of new businesses throughout Europe regardless to the nationality and location of the founder should have been a duty of Member States, with no need of intervention by European institutions. The subsequent story shows that these expectations were not met, and European Commission assumed that, due to the evident lack of interest in the subject by each Member State, a European intervention should take place. $^{29}$

26 With a special focus on identification of people in the EU, which is the starting point of the e-IDAS Regulation, extremely important to the extent of digitalisation in Company Law.

27 A Digital Agenda for Europe, p. 7-14.

28 A Digital Agenda for Europe, p. $32 \mathrm{seq}$. The italicisation is mine.

29 As already mentioned, in May 2018 a Statement of Support on a Digital Agenda for the Western Balkans was issued as well. The statement is not properly "European", as it is signed by the Heads of Government or State of six Balkan Countries, and it does not deal with Company Law in particular, even if the "capacity building in digital trust and security, in parallel to efforts to enhance digitalisation of industries" is mentioned. A truly "European" Digital Agenda for the Western Balkans was eventually launched on June $25^{\text {th }}, 2018$, and seems to be an initiative for a stronger regional implementation of the principles stated in the general "A Digital Agenda for Europe" Communication, for the development of the Single Digital Market. More details are available in the Commission Staff Working Document - Measures in support of a Digital Agenda for the Western Balkans, SWD (2018) 360 final, (https://ec.europa.eu/neighbourhood-enlargement/sites/near/files/swd_measures_in_support_of_a_digital_agenda_for_the_western_balkans.pdf), accessed on 08/08/2018, where at p. 8 there is a new statement on "the development of digital solutions that enable public administrations, 


\subsection{THE 2011 GREEN PAPER ON CORPORATE GOVERNANCE, THE 2012 ACTION PLAN AND THE 2015 SINGLE DIGITAL MARKET STRATEGY FOR EUROPE}

In 2011, the European Commission issued a Green Paper on Corporate Governance issues $^{30}$; in spite of the specialty of the subject there considered, the issues related to digitalization are almost absent in the paper. The structure of the Green Paper suggests several questions for a subsequent consultation in the area of corporate governance; while dealing with the obstacles to shareholders' cooperation, the Paper states the setting up of "shareholder cooperation fora" or listed companies' proxy solicitation system "where listed companies would be required to set up a specific function on their website enabling shareholders to post information on particular agenda items and seek proxies from other shareholders", ${ }^{31}$ alike already suggested in the Winter Report and in the 2003 Action Plan.

Also in the 2012 Action Plan issued by the Commission, the digital-related issues are almost unconsidered. As this document reports the stakeholders' replies to the 2011 Green Paper, in it the Commission takes a position on the need of shareholders' identification in order to facilitate the dialogue on corporate governance issues. Among the respondents, many advocated for the shareholders' fora to be hosted on corporate websites, as a minimal, but perhaps useful, solution. The Commission recognizes that, at least in listed companies, additional information on shareholders' identity can be useful for improving the dialogue within the company, announcing a proper initiative in 2013, but without a specific reference to digital issues.

Furthermore, in 2015 the Commission issued a Communication that could potentially deal with Company Law, focused on a Strategy for the Single Digital Market. ${ }^{32}$ In this case too, however, the connection with Company Law is just occasional, when the communication reminds that "Many Member States have

businesses and citizens in Europe to benefit from interoperable cross-border and cross-sector public services"; among them, in the field of eGovernment, the actions aiming at the online establishment of new companies.

30 Green Paper - The EU corporate governance framework, of 5 April 2011, COM (2011) 164 final, (http://ec.europa.eu/internal_market/company/docs/modern/com2011-164_en.pdf), accessed on 08/08/2018.

31 Green Paper, p. 14.

32 Communication from the Commission to the European Parliament, the Council, the European Economic and Social Committee and the Committee of the Regions - A Single Digital Market Strategy for Europe, of 6 May 2015, COM (2015) 192 final, (https://eur-lex.europa.eu/ legal-content/EN/TXT/PDF/?uri=CELEX:52015DC0192\&from=IT), accessed on 10/08/2018. 
called for action including helping companies to be formed quickly (e.g. in 24 hours). The Commission considers that any established company should be able to expand its operations cross-border online and be pan-European within a month building on the interconnection of business registers and the 'Once-Only' principle". ${ }^{33}$ We are going to see how we can find again these principles and this kind of effort in the withdrawn SUP Proposal, the Single Digital Gateway Proposal, and the Digitalization Proposal, among the others.

\subsection{THE 2016 ICLEG REPORT ON DIGITALIZATION}

After many years - at least from the 2003 Action Plan to 2015 - without a specific focus on the issue of digitalization, ${ }^{34}$ the most important document was issued in March 2016. It is the "Report on digitalization in company law", prepared by the Informal Company Law Expert Group established by the European Commission, and again formed by academics coming from different European Member States ${ }^{35}$.

The Report is the response to a specific request made in January 2015 by the Commission to ICLEG regarding the role of digitalization in Company Law, and deals with many different issues going from the use of emails for communications to the company's website, to the shareholders' meeting. The most relevant issue the report deals with is, however, the online establishment of companies; regarding this issue in particular the Report served as inspiration for the April 2018 Proposal for a Directive in the field of Digitalisation in Company Law.

From a systematic point of view, the Report contributes with its own structure to shed a light on the core distinction to be made when approaching the issue of digitalization in Company Law. On the one hand, we have the area of the "digitalization of communication between a company and the State"; 36 and, on the other hand, the "electronic communication between a company and its shareholders and other stakeholders". ${ }^{37}$ In other words, we can say that it is

\footnotetext{
33 Communication "A Single Digital Market for Europe", p. 17.

34 Perhaps with the exception of the 2014 SUP Proposal, where digital incorporation of the company was one of the core points of the draft, as we are going to point out in the next Chapter 5 .

35 The report is available online, (https://ec.europa.eu/info/sites/info/files/icleg-report-on-digitalisation-24-march-2016_en.pdf), accessed on 08/08/2018. A list of the group's members is available at p. 2, while the paper has been produced mainly by Vanessa Knapp and Jesper Lau Hansen.

36 Title of part III of the Report.

37 Title of part IV of the Report.
} 
possible to distinguish, in the general area of digitalization of Company Law, a digitalization on business environment (external digitalization); and the digitalization of companies in themselves, as for their internal structure (internal digitalization).

We are going to mention the proposals present in first part of the Report, regarding the information between the company and the State, when examining the Digitalization Proposal in next Chapter 5. We will highlight there the many similarities that can be found in such documents, bearing nonetheless in mind that such kind of digitalization deals, from a theoretical perspective, more with Public and Administrative Law than with Company Law. ${ }^{38}$ Here it seems more appropriate to focus on the intra-company communication and the ICLEG proposals, which have not been transposed in the April 2018 Proposal.

On this issue, the Report is extremely detailed and proposes several solutions for the improvement of the internal digital environment of companies, having as a guiding principle that "company law, which regulates the relationship between a company and its shareholders and which may require companies to provide information to other stakeholders, should allow for such electronic communication among these private parties". 39 This means that, except for some specific remarks addressed to publicly traded companies, the Report's proposals are intended to be applicable to all companies ${ }^{40}$ - regardless their being private or public - and to all their shareholders. The increased digitalisation the Report advocates for is intended to go along with, and not to replace, the traditional means of information and communication between the company and its shareholders: a further option for the enhancement of the quality and quickness of communication and not some kind of a "duty to update" imposed to both company and shareholders.

This being said, the core general point of the Report on this issue is to find an acceptable balance between traditional and modern views of a company that are likely to coexist in every corporate environment. This means that the European approach, in the ICLEG's idea, should be not to impose to the companies the duty to make digital procedures and tools available, that could be disproportionate; but, on the contrary, to require that the Member States "ensure that

\footnotetext{
38 The issue, in fact, is linked with the relationship between a public authority, the business register, and private bodies, i.e. the companies and the shareholders, dealing with procedures that the latter ones have to complete at the former's offices.

39 ICLEG Report, p. 23.

40 In the field of shareholders' permanent representatives, to be appointed also by means of electronic procedure, as a proposed amendment to the Shareholders' Rights Directive: ICLEG Report, p. 37 seqq.
} 
it is possible to use electronic communication"41 at least in a series of core areas identified by the Report itself. ${ }^{42}$ Once that the Member States guarantee that the information in such areas can be exercised by electronic means, it will be up to each company to decide whether it is interested in using digital tools for it, or preferable to maintain, fully or partially, the traditional "hardcopy way".

The Report shows very well to be aware of the difficulties of a choice for full digitalization in existing companies, where not all the shareholders will necessarily be in favor of such modification of their information rights. ${ }^{43}$ In this case, there is the suggestion to apply the rules "in accordance with the national corporate governance system as decided by national law"44, meaning this also with the qualified majorities possibly required by Member States, ${ }^{45}$ which "should be permitted to require additional protections for shareholders not voting in favor of full digitalization". 46

\section{$41 \quad$ ICLEG Report, p. 25.}

42 The Report states (p. 25) almost all the events of information or exercise of rights by a company's member or shareholder:

"i. any notice of a meeting of shareholders or of a class of shareholders;

ii. any form to appoint a proxy or representative to attend a meeting or otherwise exercise the shareholder's rights or revoke their appointment;

iii. voting (both to adopt a resolution and, where this is done other than by resolution, to appoint a candidate as a director);

iv. a shareholder's right to add an item to the agenda of a meeting or add a resolution to be put at a meeting or to ask a question at meeting;

v. a shareholder's right to participate at a meeting;

vi. the passing of a resolution other than at a meeting, for example by a written resolution;

vii. the right (if any) to receive notification of the results of a meeting;

viii. any right to receive the company's accounts, annual report or other financial information; ix. any information provided by the company relating to the exercise of rights by a share-holder, for example to convert a share into a different class of share;

$\mathrm{x}$. any exercise of rights by a shareholder by giving notice to the company or to a regulatory authority in relation to the company, for example to call for someone to be appointed to investigate the company's affairs;

xi. to communicate a takeover offer to the shareholders of the offeree company and for the offeree company to communicate to shareholders, employees and any other interested parties in connection with that takeover offer".

43 Wisely, the Report distinguish from this situation that of companies fully digitalised since their establishment, where there are not impediments regarding possible dissenting shareholders, as the full digitalisation in communication is one of the conditions the shareholders agreed on as of their investment; see ICLEG Report, p. 31 seq.

44 ICLEG Report, p. 25, Recommendation 15.

45 ICLEG Report, p. 32.

46 ICLEG Report, p. 33, Recommendation 24. This kind of protection could be an exit right, or less dramatically, the right to receive the information by traditional means. 
Anyway, even if the company decides for a full digitalization, the shareholders should be free to opt-out for traditional communication ad personam; ${ }^{47}$ and conversely, even where a company should decide for maintaining a traditional communication system, for instance for lack of the qualified majority in the general meeting on this issue, it "should be able to enter into an agreement with an individual shareholder as to how they will communicate".$^{48}$ In any case, the basic principles are two: on the one hand, all shareholders have to be treated equally; on the other hand, each shareholder must be free to change its mind regarding the preferred communication mean at any moment. Furthermore, as general principles for the entire system of electronic communication, the Report mentions the certainty regarding the identity of the parties involved, and the guarantee of the integrity of the communication..$^{49}$ As for the identification, it seems that the system of mutual acknowledgment established by the e-IDAS Regulation, we are going to analyse in next Chapter 5, is perfectly suitable to such purpose.

Moreover, the Report deals with a few additional issues: company's website, use of emails, general meetings.

As for the company's website, ${ }^{50}$ the ICLEG again does not advocate for a general duty of creation for every company, but in the case a company has its own website, it should be used for supplying information to shareholders and third parties as well. To this end, the website should be recognisable by everyone as truly belonging to the company. The solution to this problem is, in the idea of the ICLEG, to offer the company the option ${ }^{51}$ to file the "designated homepage" in the business register, so to make everyone aware of which one, among the many websites a big company could possibly have, is the relevant for official communications. This solution, together with the Business Register Interconnection System, ensures a widespread knowledge of the website, and consequently of the information there contained. As for the communication, the ICLEG suggest that the "designated homepage" could be used "to provide information that is mandated by law (whether national law or EU law)", 52 along

\footnotetext{
47 ICLEG Report, p. 30.

48 ICLEG Report, p. 30.

49 In many loca; see for instance ICLEG Report, p. 24 seq., Recommendation 14.

50 ICLEG Report, p. 26 seqq.

51 But the ICLEG states that "It would be worth considering whether there should be an obligation for certain companies with a homepage to register it as a designated homepage and, if so, whether this should apply to all companies or only to publicly traded companies" (p. 28). See also below, para. 5.4.3, regarding a possible joint use of the website and the information filed in the register.
}

52 ICLEG Report, p. 28. 
with - and thus not replacing to any extent - the filing in business register. ${ }^{53}$ One of the proposals in this sense is to have some basic information ${ }^{54}$ regarding the company and already filed in the national business register somehow "mirrored" in the website too, ${ }^{55}$ so to facilitate the public knowledge of it, free of charge. ${ }^{56}$

Besides the pure public information, another meaningful role the company's website could be likely to play deals with the information supplied, on request, to shareholders and other entitled people. The ICLEG Report, founding its proposal on the provisions contained in e-IDAS Regulation, suggests that European institutions should explicitly allow companies to keep all their records in a digital secure format, with electronic seals, if they want. In order to make this provision effective also from shareholders' point of view, the ICLEG proposes that "those entitled to have access to the information should be able to request access electronically and whether companies should be able to, or required to, provide the information electronically", at least in publicly traded companies. ${ }^{57}$ In this case, the most suitable and effective means for the exercise of this access right seems to be the company's website, even if this is not explicit in the Report, and in any case provided that the foreseeable European legal instrument for this purpose enacts a series of cautions. ${ }^{58}$ More functions for the company's website can be linked to the general meeting's information, as we are going to see in a while.

\footnotetext{
53 In the traditional way, or in the digital one the ICLEG advocates for, and that we are going to analyse in next Chapter 5.

54 "15.11. The information to be set out on the website could include the information available at the national business registry, such as company's full name and registered number, where it is registered, its registered office, the names of the directors, who is authorised to enter into agreements on behalf of the company and to represent it in legal proceedings, the company's most recent ac-counts or if it is not required to prepare accounts, that fact, and whether the company is subject to insolvency or winding up or similar proceedings. We believe that this information should be availa-ble on the website in a standard format in addition to being available via the national business reg-istry and the e-justice portal so that it is readily available for free to someone using that website": ICLEG Report, p. 29.

55 Or, at least, with a link to the relevant page in the business register.

56 But at the same time with the risk to have diverging information in the register and the company's website.

57 ICLEG Report, p. 33. See also below, para. 5.3.3.

58 "Any such consideration should include: i. how the company would check that the request comes from someone entitled to access the in-formation; ii. what safeguards should be applied to ensure the information is used for the purpose for which it is intended and not for other purposes; and iii. whether there are cases where it would be inappropriate to provide information electronically": ICLEG Report, p. 34, Recommendation 25.
} 
Regarding the use of email addresses, the Report simply proposes that, once that a company decides to adopt electronic means of communications, it should be required to disclose to the public at least one email address, filing it in the register, and mentioning it in its website. ${ }^{59}$

Finally, the ICLEG Report deals with the general meetings and the possibilities for an improvement of their digitalization. ${ }^{60}$ On this subject, the ICLEG approach goes by far beyond the sole issue of digitalization. More precisely, starting from digitalization and the opportunities offered by its enhancement, the Report reaches really relevant systematic consequences; and this in spite of declaring that "[t]he possibilities of digitalization contemplated here do not in any way seek to influence the distribution of powers in national Company Law; it is solely intended as a reform of the practical forms of communication that are used in connection with the various national corporate governance models". ${ }^{61}$ And, again, the proposed digital solutions are, in ICLEG's mind, to go along with traditional information structure, without replacing it, nor dispensing with the general meeting information, or with the idea of general meeting itself. ${ }^{62}$

The ICLEG's overall idea on the subject is that the traditional model is based on a "one-way" communication: the company supplies information to the members/shareholders, before, during and after the meeting; and, at least in some jurisdictions, the members are entitled to ask questions to the management, receiving replies during the meeting. It is, in other words, a soliloquy, while the entire company would instead benefit of a dialogue. Digital tools established by the company could be the means to achieve the goal of a more effective "two-ways" communication, or a dialogue. ${ }^{63}$ A dialogue that could take place not only between members and management, but even between members themselves, being this way that sort of forum that already the 2011 Green Paper and the 2012 Action Plan advocated for.

This kind of dialogue would be extremely facilitated by the new digital structure; facilitated to that extent that the ICLEG proposes even to abandon the same concept of "extraordinary meeting", being it "simply a part of the ongoing communication between a company and its constituencies". ${ }^{64}$ By this way, the Report suggests a reconsideration of the general distinction between the

\footnotetext{
59 ICLEG Report, p. 29.

60 As for proxies in publicly traded companies, see above, ref. 40.

${ }^{61}$ ICLEG Report, p. 34 seq.

62 Ibidem.

63 ICLEG Report, p. 35.

64 Ibidem.
} 
notice required for Annual General Meetings, and the remaining shareholders' communication facilities. ${ }^{65}$

Besides these insightful remarks, which however have not been transposed at all in the Proposal, the remaining ones deal with external digitalization in Company Law, and we are going to mention them when analyzing the April 2018 Proposal for a Directive.

\section{THE EXISTING LEGAL PROVISIONS DEALING WITH DIGITALIZATION IN EUROPEAN COMPANY LAW}

If we consider both of the facets of digitalization we have found in the ICLEG Report, and thus its internal and external dimensions, we can recover traces of them already in many pieces of legislation of the European Company Law already in force.

\subsection{THE CODIFIED DIRECTIVE}

In June 2017 the European Parliament resolved to codify in a single Directive many of the previous Directives regarding disclosure of company's (First Directive and later amendments ${ }^{66}$ ) and branches' (Eleventh Directive ${ }^{67}$ ) information, constitution and capital (Second Directive and its amendments ${ }^{68}$ ), domes-

65 Finally, for publicly traded companies the Report states a proposal suggested by some companies "that it should be possible for them, with shareholder approval and subject to certain safeguards, to be able to dispense with any requirement for a physical meeting", having this way just virtual AGMs: ICLEG Report, p. 35 seq. And Recommendation 26.

${ }_{66}$ Being the last version available before the codified Directive the Directive 2009/101/EC of the European Parliament and the Council, of 16 September 2009, on coordination of safeguards which, for the protection of the interests of members and third parties, are required by Member States of companies within the meaning of the second paragraph of Article 48 of the Treaty, with a view to making such safeguards equivalent, (OJ L 258, 01/10/2009).

67 Eleventh Council Directive 89/666/EEC of 21 December 1989 concerning disclosure requirements in respect of branches opened in a Member State by certain types of company governed by the law of another State, (OJ L 395, 30/12/1989.

68 Last version available before the codification: Directive 2012/30/EU of the European Parliament and the Council, of 25 October 2012, on coordination of safeguards which, for the protection of the interests of members and others, are required by Member States of companies within the meaning of the second paragraph of Article 54 of the Treaty on the Functioning of the European Union, in respect of the formation of public limited liability companies and the maintenance and alteration of their capital, with a view to making such safeguards equivalent, (OJ L 315, 14/11/2012). 
tic mergers (Third Directive and amendments ${ }^{69}$ ) and divisions (Sixth Directive and amendments ${ }^{70}$, and cross-border mergers. ${ }^{71}$

This work of codification ${ }^{72}$ gave birth to a document rather similar to a basic "European Company Law Code", not yet uniformed as of its application, as some provisions apply to both public and private companies, and others to just some of them, nor in its overall structure, as only a few issue are actually regulated. In any case we can now rely on a codified and updated text dealing with many of the most relevant issues in European Company Law. This means that such text, the Directive 2017/1132, hereinafter also just "Codified Directive", is also perhaps the best place in order to appreciate the degree of digitalization the European Company Law reached before the April 2018 Proposal.

In many articles, we can find references to "electronic means", with a definition at article $16.2,{ }^{73}$ which is the fundamental article also with reference to disclosure - and Business Register Interconnection System - object of meaningful proposals of amendment by the April 2018 Proposal. In many others the citation of the company's website as an alternative mean of information even instead of the publication, in some cases.

More in detail, the External digitalization is at large present in the rules regarding the business register contained in articles 16 seqq., which lay down some obligations for Member States as for the electronic registration of documents and particulars required by article 14 , converting in digital form those previously filed in hardcopy.

69 Last version available before the codification: Directive 2011/35/EU of the European Parliament and the Council, of 5 April 2011, concerning mergers of public limited liability companies, (OJ L 110, 29/4/2011).

70 Sixth Council Directive of 17 December 1982, based on Article 54 (3) (g) of the Treaty, concerning the division of public limited liability companies (82/891/EEC), (OJ L 378, 31/12/1982).

71 Directive 2005/56/EC of the European Parliament and the Council, of 26 October 2005, on cross-border mergers of limited liability companies, (OJ L 310, 25/11/2005).

72 From which the Directive (EU) 2017/1132 of the European Parliament and the Council of 14 June 2017, relating to certain aspects of company law, (OJ L 169, 30/06/2017) originated.

73 ' 2 . For the purposes of this Article, 'by electronic means' shall mean that the information is sent initially and received at its destination by means of electronic equipment for the processing (including digital compression) and storage of data, and entirely transmitted, conveyed and received in a manner to be determined by Member States by wire, by radio, by optical means or by other electromagnetic means". The definition at large recalls the notion given by Transparency Directive: see above ref. 25. For the suggestion of its repeal made by the Proposal, see below, para. 5.4.2. 
Interested parties are free to apply for copies of disclosed information, even if, very curiously, while paper copies supplied to applicants are certified as "true copies" unless otherwise required by the applicant, the regime for electronic copies is exactly reverse, being them not certified as "true copies" unless the applicant "explicitly requests such certification". 74 The application for copies of the disclosed information can be made also for foreign registries, through the system of interconnection of registers (BRIS), according to article 18 of the Codified Directive. At least the information and particulars listed in article 14 are to be accessible through the BRIS, with a research system provided by the European Commission. More details regarding the BRIS are available at articles 22-25 of the Codified Directive; its momentous role for the development of an actually Single Market is to be as highlighted as possible. By means of this system, at least the basic business information is made really available throughout the Union, minimizing the linguistic issues, and increasing the unification of filing standards. In order to have no uncertainty regarding the searched company, it is necessary that each company has a "unique identifier allowing them to be unequivocally identified in communications between registers through the system of interconnection of central, commercial and companies registers" 75 ; the same provision is established also for branches, for the same purposes. ${ }^{76}$

Besides the registers, which the Member States are owed to operate in a digital form, the Codified Directive establishes also an option for keeping in electronic form the national gazette where some basic information is to be published pursuant article 16.3. Another, even more radical option the Directive offers the Member States is to replace the publication in the national gazette, regardless of its paper or electronic form, with alternative means, provided that such means allow that the disclosed information "can be accessed in chronological order through a central electronic platform".77

Another key issue the Codified Directive deals with, in many articles and different subjects, is the company's website. Although for its own nature the website belongs, by itself, to the idea of internal digitalization, in the terms already discussed, the way it is used by the Codified Directive make of it some kind of a "bridge" between internal (as it is developed and issued by the companies) and external (due to its function of common information we are going to analyze in a while) digitalization.

74 Codified Directive, article 16.4.

75 Codified Directive, article 16.1.

76 Codified Directive, article 29.4.

77 Codified Directive, article 16.5. 
Its importance is obviously paramount, but there is not a comprehensive regulation regarding the information it must contain, and this makes comprehensible the focus on it by the ICLEG Report. Furthermore, and above all, there is not a general duty for companies to have a website, and all the provisions laid down are thus applicable just to those companies that voluntarily decided to have a website. The first rule we can find lays down that Member States must ensure that the company's websites contain the same information to be supplied to the public in the letters and order forms (information on identification, comprising the relevant register and the unique identifier, and on company's legal form and seat), along with the mention of the capital subscribed and paid up. ${ }^{78}$

The mayor importance of websites is, nonetheless, when it comes to the mergers (domestic and cross-borders) and divisions of companies, where the norms explicitly state that some information can be published in the company's website instead of the register. ${ }^{79}$

As a general remark, we can say that, with reference to the issues here under discussion, the rules set down for domestic mergers are the same in force for cross-border mergers and, with the obvious replacement of the term "merger" with "division", for domestic divisions as well. What we are going to say applies, thus, to these three legal phenomena exactly in the same way.

The draft terms of mergers and divisions are to be disclosed, as it responds to a general interest, beside those of the members and shareholders of the merging or dividing companies to have knowledge of the terms of such operations. The general rule for disclosure is, obviously, that set down by article 16, with the filing of information - and draft terms are part of such information - in each register for each involved company, followed by publication in the national gazette, or the alternative equally effective electronic mean decided by the Member State. For the operation we are discussing about, nonetheless, besides this "traditional" way, there are two additional possibilities, the literature commonly sees as alternative to the disclosure through the filing in the national register. ${ }^{80}$

78 Codified Directive, article 26, with the penalties for failure in complying set down by article 28.

79 This is, at least, the reading of the rule provided for by the leading textbooks in European Company Law: Grundmann, S.: European Company Law, Cambridge - Antwerp - Portland, 2012, p. 680; Dorresteijn A.F.M. et al, European Corporate Law, Alphen aan den Rijn, 2017, 72.

80 See Codified Directive, articles 92 (domestic mergers), 123 (cross-border mergers), and 138 (divisions). Even if that in the text is the mainstream reading, it is my opinion that the alternatives laid down in the mentioned articles and described in the text are not to the whole system of disclosure, comprehensive also of the filing of the draft terms in the register, but just to the second part of it, i.e. the publication. In fact, the article 92 and its clones mention the exemption "from the publication requirements laid down in Article 16", where, article 16 mentions "pub- 
On the one hand, it is possible to be exempted from publication when the draft term have been made available free of charge in the company's website "for a continuous period beginning at least one month before the date fixed for the general meeting which is to decide on the draft terms of merger and ending not earlier than the conclusion of that meeting". ${ }^{81}$ By this way, the company's website serves as a public disclosure means, and the Member States only are entitled to set those proportionate restrictions required in order to "ensure the security of the website and the authenticity of the documents".

The second alternative passes through the same central electronic platform we already saw as an alternative to the publication in the national gazette, pursuant article 16.5 , or other alternative websites, designated by the Member States and whose content is available free of charge. Even if in this case the platform or the website are not kept by the company itself, there is no doubt that we have here too an example of digitalization.

There is, then, a second set of rules where the company's website plays a meaningful role, in its internal dimension. We are referring to articles 97 and 143 laid down regarding the documents for inspection by shareholders in the case, respectively, of domestic mergers and divisions. Before the general meeting called for deciding on the merger or the divisions, the shareholders have the right to inspect a series of documents regarding the operation; ${ }^{82}$ such inspection may oc-

lication" just in 16.5, referring to a second disclosure of the documents, the one to occur in the national gazette designated by each Member State. The derogation SUPplied by articles 92 , 123 and 138 should thus be intended just to the part on the publication on the national gazette - that, by the way and as we saw, could be kept in electronic form as well - being in any case maintained the duty to disclose the document in the national register.

81 And with the possibility of the Member Stats to extend the period of publication on the company's website, or the alternative eletronic platforms or sites mentioned by the norm: see for instance article 92, paragraph 6.

82 Codified Directive, article 97.1: "1. All shareholders shall be entitled to inspect at least the following documents at the registered office at least one month before the date fixed for the general meeting which is to decide on the draft terms of merger:

(a) the draft terms of merger;

(b) the annual accounts and annual reports of the merging companies for the preceding three financial years;

(c) where applicable, an accounting statement drawn up on a date which shall not be earlier than the first day of the third month preceding the date of the draft terms of merger, if the latest annual accounts relate to a financial year which ended more than six months before that date; (d) where applicable, the reports of the administrative or management bodies of the merging companies provided for in Article 95;

(e) where applicable, the report referred to in Article 96(1).

For the purposes of point (c) of the first subparagraph, an accounting statement shall not be required if the company publishes a half-yearly financial report in accordance with Article 
cur at the company's registered office, or, as an alternative pursuant article 97.4 (and 143.4), by browsing the company's website. According to the cited rules, in fact, company is exempted from making the documents available at its registered office if they are present in its website, at least during one month before the meeting. In addition, the company has the right to refuse to provide copies of such documents if they are downloadable and printable from the website. ${ }^{83}$

\subsection{THE REVISED SHAREHOLDERS' RIGHTS DIRECTIVE}

Along with the Codified Directive, another piece of legislation currently in force contains many references to digital profiles, even if they are applicable only to "companies which are admitted to trading on a regulated market situated or operating within a Member State": the revised shareholders' right Directive (hereinafter RSRD) ${ }^{84}$

Already in the original version of the Directive, as of 2007, a few references to digital profiles were present; they have been increasingly enhanced in the revised version approved in 2017, with amendments dealing with the identification of the shareholders and their proxies. In these newer provisions, the main characters are the websites, and not just the company's one, as we are about to see. It seems that, even if there is not a specific obligation laid down in the black letter of the law, for the companies subject to the RSRD an implicit obligation to have and keep a website, for the purposes we are going to analyze in a while, still exists.

The leading principle of the RSRD is the urgency to provide shareholders with more tools for exercising their rights within the company, fighting by this way the so-called shareholders' apathy. From this point of view, the shareholders' participation may take place either directly, enabling the shareholders to take part into the company's meetings even without being physically present; or via representatives, by regulating the proxy voting and facilitating an aware appointment of proxy holders.

5 of Directive 2004/109/EC and makes it available to shareholders in accordance with this paragraph. Furthermore, Member States may provide that an accounting statement shall not be required if all the shareholders and the holders of other securities conferring the right to vote of each of the companies involved in the merger have so agreed".

83 A final reference to digitalisation can be found in the Codified Directive at article 24(k) and Whereas 37 of the Preamble, where online payments are considered in order to ensure that the BRIS can work if the applicants requiring information subject to a fee pays it by means of a foreign payment system. This provision, evidently part of the "external" digitalisation, is set down in order to preserve the actual function of the interconnection of the registers.

${ }^{84}$ Full references above, ref. 15 and 16. 
In order to exercise their rights, a previous information regarding how to do that is needed; for this purpose, the company has the duty to inform shareholders and intermediaries regarding them, either directly, or indicating the part of the company's website where such information is available. ${ }^{85}$

The key corporate event for shareholders' participation is, of course, the general meeting. Before, during and after this event, digital tools play a relevant role for improving shareholders' information, mainly through the company's website.

As for pre-meeting information, the convocation - whose formalities can be different for the annual general meeting, and the other general meetings when the company allows its shareholders to vote by electronic means, being the requirements stricter for the former ${ }^{86}$ - must contain some information, again on the shareholders' rights and their terms of exercise. It is possible for such communication simply to cross-reference the company's website if more detailed information is available there. The company's website has, or at least could have, this first function to supply information regarding shareholders' rights and ways of their exercise. ${ }^{87}$

Again, the convocation contains information on the proxy voting, comprehensive of the forms and information on electronic acceptance of the appointment by the company ${ }^{88}$ and on the exercise of the voting rights by correspondence or by electronic means. Finally, the convocation must report the company's website where additional information is to be made available by the company.

Pursuant to article 5.4, the informative function of the company's website includes:

- A copy of the convocations for the general meeting;

- The mention of the total number of shares issued by the company, the voting rights attached to them, and the distinction between classes of shares;

\footnotetext{
85 RSRD, article 3b.1.

86 The common means of convocation is the publication in the press; the RSRD allows that, in companies where the identification of shareholders it is possible, "provided that the company is under an obligation to send the convocation to each of its registered shareholders" (RSRD, article 5.2). In this case, even if it is not made explicit by the Directive, seems reasonable that the despatch of the convocation could take place by electronic means as well.

87 Given the reading of the rule, it seems that this is not a compulsory content of the website, as the company could provide the same detailed information just in the convocation. In any case, as pursuant to RSRD article 5.4(a) the website must contain the convocation, this information will in any case be available in the company's website.

88 This kind of acceptance is likely to occur, for instance, by accepting appointments via email, or having a dedicated section of the company's website where the appointing shareholders could upload the documents.
} 
- The documents to be submitted to the general meeting, inclusive draft resolutions prepared by the company's management and tabled by the company's shareholders themselves, even electronically, pursuant to article $6.1 ;{ }^{89}$

- Forms for the appointment of proxy holders.

Again with reference to pre-meeting information, the website is likely to serve as a means for not just one-way information from the company to its shareholders, but for a two-ways too, facilitating the exercise of shareholder's right to ask question. Clearly, each shareholder has the right to ask questions, and receive answers, during the general meeting; it is nonetheless possible that this right is made exercisable even before the meeting, allowing an exchange of information between shareholders and the company's management. Nevertheless, as sometimes the right to ask question could turn into an abuse by disturbing minority shareholders, it is possible that the company's website contains a FAQ section, and the answers there provided serve as a valid answer to relevant questions asked by shareholders, waiving by this way the management to provide ad personam replies. ${ }^{90}$

Finally, among the general information to be provided in the company's website there are also communications regarding the company's remuneration policy for their directors, and the remuneration report, ${ }^{91}$ besides the detailed results of every vote that took place during the meeting. ${ }^{92}$

Moving to the moment of the general meeting, the general provision is that Member States must permit the shareholders' (and their representatives') participation by electronic means. The Directive highlights how these electronic means can be of three different types, which are not in alternative each other, but combinable:

- Real time one-way communication, where the subjects entitled to participate in the meeting only have the possibility to watch and listen the broadcasting, without interacting;

- Real time two-ways communication, with the possibility for the remotely present shareholders to interact with the meeting, e.g. by asking questions;

\footnotetext{
89 Again, it shall be possible that such electronic means comprehend proposal via email, or uploading in a specific section of the itself.

$90 \quad$ See RSRD, article 9.2.

91 RSRD, articles 9a.7 and 9b.5, respectively.

92 RSRD, article 14.2.
} 
- "With a mechanism for casting votes, whether before or during the general meeting, without the need to appoint a proxy holder who is physically present at the meeting". ${ }^{3}$

As for the last point, such mechanism can obviously be also the vote by correspondence in advance of the general meeting, pursuant article 12. To our extent, however, it is much more interesting when the votes can be electronically cast,${ }^{94}$ by shareholders or by their representatives. In this case it is necessary that "an electronic confirmation of receipt of the votes is sent to the person that casts the vote". ${ }^{95}$ Such confirmation must, thus, be sent to the voting person, whether the shareholder or a representative/proxy.

This remark leads us to consider the issue of proxy voting, that is central to the 2017 amendments to RSRD, with profiles of digitalization as well. There are two core principles on this issue:

- it should be possible for the shareholder to appoint the proxy in the quickest, safest, and most effective way;

- the shareholder must have the possibility to check whether the proxy holder followed the instructions, or not.

As for the first principle, we have already seen that instructions and forms are to be supplied to the shareholders along with the convocation for the meeting. ${ }^{96}$ Regarding the certainty about how the representative voted, the confirmation to be sent to who cast the vote, pursuant article $3 \mathrm{c} .2$ is to be sent, after the meeting, to the shareholder or to a third party nominated by the shareholder. ${ }^{97}$ The second principle naturally deals with the reliability and the confidence the shareholder has towards the proxy.

There are some cases where the shareholder's voting policies should be public for the advantage of the market; this happens in particular when there are institutional investors and asset managers. In these cases, the RSRD lays down the rule that such subjects have to disclose their engagement and voting policies

\footnotetext{
93 RSRD, article 8.1.

94 Provision explicitly considered under RSRD, article 5.3(b)(iii), since the original version of the Directive.

95 RSRD, article 3c.2, addedd with the 2017 amendments.

96 Much more in detail, RSRD, article 11, also for the revocation of appointment. And, regarding the useful "permanent representative" proposal by the ICLEG, see above, in paragraph 2.5.

97 And, even if here too there is no explicit mention of an electronic communication in this case, seems that there are no problems in having it sent by electronic means. Furthermore, this after-meeting information only is mandatory if it is not already available to the shareholder, or the third party designated by the shareholder.
} 
in their websites, along with investment strategies. ${ }^{98}$ Furthermore, a duty of transparency is laid down also on proxy advisors, regarding the application of a code of conduct, and other sensitive issues related to the vote. ${ }^{99}$ They have to supply such information in their website as well.

\subsection{THE ACCOUNTS DIRECTIVE}

A couple of references to digital-related issues are, finally, available also in the Directive on annual and consolidated financial statements. ${ }^{100}$ They are mainly technicalities ${ }^{101}$ but witness the progressive digitalization of the area of accounting as well.

This is clear since the statement in the Preamble that: "The Member States are strongly encouraged to develop electronic publication systems that allow undertakings to file accounting data, including statutory financial statements, only once and in a form that allows multiple users to access and use the data easily. With regard to the reporting of financial statements, the Commission is encouraged to explore means for a harmonized electronic format. Such systems should, however, not be burdensome to small and medium-sized undertakings" 102 . This principle finds its material declination in article 4.8 of the directive, with exemption from additional disclosure for SMEs publishing electronically their financial statements.

Furthermore, when a company prepares a separate non-financial statement, not enclosed to the management report, there is the mandatory provision to make it public on the company's website. ${ }^{103}$ Equally on the company's website is to be published the corporate governance statement, if not enclosed in the management report. ${ }^{104}$

98 RSRD, articles 3g.2 and 3h.3. In the mentioned cases, we can argue that such websites are to be mandatorily held by those companies and subjects.

99 RSRD, article $3 \mathrm{j}$.

100 Directive 2013/34/EU of the European Parliament and of the Council, of 26 June 2013, on the annual financial statements, consolidated financial statements and related reports of certain types of undertakings, amending Directive 2006/43/EC of the European Parliament and of the Council and repealing Council Directives 78/660/EEC and 83/349/EEC, (OJ L 182, 29/6/2013), hereinafter also just Accounts Directive.

101 For instance, see Accounts Directive, article 9,4 and Whereas 20 on the derogations in the layouts "if necessary for the electronic filing of financial statements".

102 Accounts Directive, Whereas 39. Italicisation is mine.

103 Accounts Directive, article 19a.4(b).

104 Accounts Directive, article 20.2(b). As in the case above in ref. 98, here too it seems that the mentioned companies have the mandatory obligation to have a website. 


\section{THE ONCOMING LEGISLATION: THE SINGLE DIGITAL GATEWAY PROPOSAL}

Before considering the April 2018 Proposal, whose destiny is still unclear mainly due to the forthcoming end of the European legislature, it is worth considering very briefly a Proposal for a Regulation issued by the Commission in May 2017 and currently with good possibilities to be adopted in short terms: the Single Digital Gateway Proposal (hereinafter SDGP). ${ }^{105}$

It is important to make it clear since the very beginning that the SDGP does not deal with Company Law in a direct way. The proposal has several profiles of interest for Company Law, but its scope of application is not that. Even more precisely, its - broad - scope of application covers many legal sectors and areas, but explicitly excludes Company Law. ${ }^{106}$ This is due to two joint factors: on the one hand, the SDGP has been issued by the Commission's Internal Market directorate general, while Company Law issues are currently belonging to the competences of the Justice directorate. On the other hand, Company Law has many specificities that barely can be regulated by a "one size fits all" piece of legislation being more opportune to deal with such issues through a more tar-

105 Proposal for a Regulation of the European Parliament and of the Council on establishing a single digital gateway to provide information, procedures, assistance and problem solving services and amending Regulation (EU) No 1024/2012, of COM (2017) 256 final, of 2 May 2017, [https://eur-lex.europa.eu/legal-content/EN/TXT/PDF/?uri=CELEX:52017PC0256\&from=EN], accessed on 13/08/2017.

The Proposal has been examined by the Council that on June 15th 2018 issued a final compromise text with a view to agreement, Council document 10069/18, available online [https://eurlex.europa.eu/legal-content/EN/TXT/PDF/?uri=CONSIL:ST_10069_2018_INIT\&from=IT], accessed on 13/08/2018. As the just mentioned text is the most advanced version of the proposal, and the one with the most realistic expectation to be approved even in short terms, in this article we will cite this version.

According to a Commission's press release of July 12th, 2018, the formal approval by the Parliament and the Council is expected in September 2018, after that in July 2018 the Parliament's Internal Market and Consumer Protection Committee agreed on the text approved by the Council. Details: [https://ec.europa.eu/luxembourg/news/commission-welcomes-agreement-single-digital-gateway_fr], accessed on 13/08/2018.

106 See SDGP, Whereas 23 of the Preamble: "In order to allow citizens and businesses to directly enjoy the benefits of the internal market without unnecessary additional administrative burden, this Regulation should require full digitalisation of the user interface of certain key procedures for cross-border users (...). This Regulation should not cover the initial registration of a business activity nor the procedures leading to the constitution of companies or firms as legal entities or any subsequent filing by such companies or firms, as such procedures necessitate a comprehensive approach aimed at facilitating digital solutions throughout a company's lifecycle (...)"; italicisation is mine. 
geted document. ${ }^{107}$ In any case, the Proposal on Digitalization in Company Law explicitly makes references to the SDGP, as we are going to observe in a while.

The goal of the SDGP is to establish a Single Digital Gateway - in the Proposal it is stated that it should be the existing website "Your Europe"108 - in order to facilitate cross-border activities - not necessarily economic activities - for European citizens and enterprises. Such a purpose should be achieved through a system that guarantees to the beneficiaries low-cost and high-level verified information, the reduction of boundaries and fulfilments, and the possibility to get all the required information online. The areas interested by this proposals are listed in Annexes I (information to be supplied by the Gateway) and II (online procedures whose access must be possible via the Gateway), and deal with many profiles, from travel to work and retirement, to automobiles management, from residence to education, healthcare and family rights.

The SDGP is interesting for our purposes for two main reasons. We have the guiding principles for this Proposal, that are very much compatible, if not even inspiring for those contained in the later Proposal on digitalization in Company Law; and we can find there a set of rules that, even if are not directly applicable to companies in their large majority, are nevertheless a part of the overall business environment.

Looking at this latter profile first, we can see that it is present in both of the Annexes on information and digital procedures. This is very much consistent with the philosophy apparently underlying the Proposal: "First, Understand; Second, Act".

As for information that the Single Digital Gateway must provide for each Member State, ${ }^{109}$ Annex I has a specific section dealing with business. Information are to be provided in a digital way with regard to starting, running and closing a business, ${ }^{110}$ a firm's staff (employment law, social security, equal

107 In addition, while the SDGP is a Regulation, the Proposal on Digitalisation in Company Law of April 2018 is on the contrary a Directive, which is, by the way, the most common legislative tool the European institutions use in the field.

108 SDGP, Whereas 62 and articles 2.1, 18.1, 22.1

109 Pursuant to SDGP, article 2.2(a): "The gateway shall give access to:

(a) information on rights, obligations and rules laid down in Union and national law, which are applicable to users exercising or intending to exercise their rights derived from Union law in the field of the internal market in areas listed in Annex I".

110 Comprehensive of transformation and cross-border conversion; by this way, this area covers the issues dealt with by the Proposal on Digitalisation of April 2018, along with those contained in the accompanying proposal on cross-border conversions, mergers and divisions. This area includes also the information on intellectual property, commercial practices, 
treatment, health and safety at work); taxes to be paid; goods and services (license, competition, certifications, production, disposal...); business' means of funding; public contracts. In other terms, the Single Digital Gateway should be a repository of information, provided by each Member State at least in two languages (the Member State's official one, and "an official language of the Union broadly understood by the largest possible number of cross-border users", ${ }^{111}$ reasonably English), accurate and rather synthetic, allowing businessmen to better understand the legal environment of the Member States where they are interested in investing in.

Regarding the online procedures whose completion is to be entirely possible through the Single Digital Gateway, ${ }^{112}$ the Annex II mentions in particular the possibility to notify the starting of a business activity or to request online via the Single Gateway the permission to start a business, if any. Here too, however, it is explicitly stated that the "initial registration of a business activity with the business register", the "constitution of or any subsequent filing by companies or firms within the meaning of the second paragraph of Article 54 TFEU", along with the termination of business activity involving insolvency or liquidation procedures are not regulated by the Proposal. ${ }^{113}$ The Single Digital Gateway can thus be used in order to fulfil online some business-related requirements, but not to register a company, nor to record filings in the register; for these purposes, the digital tools provided for by the April 2018 Proposal on digitalization should be used.

cross-border online payments and e-commerce; insolvency, credit insurance, rights and obligations arising from contract law; civil liability of directors; processing of personal data.

111 SDGP, Whereas 35.

112 SDGP, article 6.1. In the original version, the rule was in article 5.2; the Council compromise, however, added to the text a part quite dangerous for the effectiveness of the provision, as Member States must ensure that "users can access and complete any of the procedures listed in Annex II fully online", but this only "where the relevant procedure is established in the Member State concerned". This naturally means that where these procedures are not established in a Member State, there is no obligation under the SDGP for such Member State to establish them.

113 This means, however, that we have a grey area regarding, for instance, partnerships: as the derogation regarding initial registration and subsequent filing is motivated by the fact that such issues are dealt with by the April 2018 Proposal on digitalisation, we have to point out that this latter Proposal only deals with companies. On the other hand, the concept of partnership is within the notion of "company or firm" under article 54 TFEU, and thus out of scope of application of the SDGP, but also excluded from the scope of application of April 2018 Proposal on digitalisation. This means that no online procedure is available for this kind of firm; even if this is not a serious issue due to the very nature of partnerships, in most cases very much linked to the Member State where it is established and where its members are resident, from a systematic point of view this represent a gap in the overall system. 
A few theoretical principles we can find in the SDGP are even more relevant for a better understanding of the Proposal on digitalization. They deal with:

- the basic information system, in order to spread detailed and qualified information regarding legal provisions currently in force in each Member State;

- the equivalency between domestic and foreign European citizens, ${ }^{114}$ allowing the former and the latter to access to online procedures on the same basis, and this also thanks to the implementation of identification measures based on the e-IDAS Regulation; ${ }^{115}$

- the implementation of the "once-only" (una tantum) principle, meaning this, as for cross-border application, that "citizens and businesses should not have to supply the same data to public authorities more than once and that $\mathrm{i}[\mathrm{t}]$ should also be possible to use this data at [ ]a the request of the user for the purposes of completing cross-border online proc[e]dures involving cross-border users". ${ }^{116}$

The mentioned principles are paramount as for a complete comprehension of the Proposal on digitalization, as it is to be intended as some kind of completion of the draw starting with the SDGP, namely regarding the profiles linked to Company Law. This being said, we are now ready to start the analysis of the Commission's Proposal on digital tools and processes in Company Law.

\section{THE APRIL 2018 PROPOSAL ON DIGITALIZATION IN EUROPEAN COMPANY LAW.}

As already several times reminded, on April 25 ${ }^{\text {th }}, 2018$, the European Commission issued a series of initiatives, called "Company Law Package" aiming at the modernization of European Company Law. ${ }^{117}$ One of them deals directly with the issue of digitalization, proposing amendments to the Codified Directive (EU) 2017/1132 in order to increase its level of recourse to digital processes: ${ }^{118}$ such a proposal is the logic follow-up of the already described

\footnotetext{
114 SDGP, Whereas 7, 8, 18 and article 13.

115 SDGP, Whereas 21 and 70.

116 SDGP, Whereas 44 (but also 12, 26, 42, 52, 72; and articles 1.1(b) and, in particular, 14).

117 For full details see above reff. 1 and 13.

118 Due to the fact that the Proposal has been released very recently, there are almost no commentaries on it, apart from Knaier, R.: Digital first, Bedenken second?, GmbH-Rundschau, 2018, 11, p. 560; Biermeyer, T. and Meyer, M.: European Commission Proposal on Corporate Mobility and Digitalization: Between Enabling (Cross-Border Corporate) Freedom and
} 
ICLEG Report, even if not all the remarks contained in the Report have been actually transposed in the Commission's Proposal. In general, we can rather say that the Commission only implemented in the Proposal those suggestions regarding the "external digitalization", leaving almost no room to internal one. ${ }^{119}$ Moreover, a part of the suggested amendments is not applicable to every company forms but only to some of them, namely those mentioned in the on-purpose added Annex IIA (private companies).

The Proposal has only five articles, and all the proposed amendments to the Codified Directive are in article 1; in order to make the referencing simpler and more understandable, we are going to refer to the proposed amendments as, e.g. "proposed" or "new article 13c", instead of the more correct and formal "article 1.3 sub article $13 \mathrm{c}$ ".

\subsection{THE STRUCTURE OF THE PROPOSALS}

The Proposal deals with three main issues on digitalization in the strict sense; a couple of additional subjects are present, too, but they deal only partially with digitalization.

There is some kind of a "General part" on digital issues, the proposed articles $13 \mathrm{a}$ to $13 \mathrm{e}$, dealing with definitions, identification means, fees and payments and information to be made available online by Member States.

These general provisions are followed by the core part of the document, providing for new rules on a company's online registration and online filing of particulars (proposed articles $13 \mathrm{f}$ to $13 \mathrm{i}$ ); these rules are almost entirely applicable to the company's branches by virtue of new articles $28 \mathrm{a}$ to $28 \mathrm{c}, 30 \mathrm{a}$ and the new subparagraph added to article 31.

The provisions just partially related with digitalization are in particular those contained in the proposed article $13 \mathrm{~h}$ on disqualified directors, whose application goes by far beyond the sole digitalization of companies, ${ }^{120}$ and in the pro-

Fighting the 'Bad Guy', European Company Law, 2018, p. 110. As we are going to see in a few moment, in spite of not having yet literature on the Digitalisation Proposal, a large part of the commentaries on the SUP Proposal are still useful to our purposes.

119 At the present day - August 2018 - it is still too early to say whether suggesions in the area of "internal digitalisation" are going to be added to the text at a later stage, for instance as a consequence of the analysis of the text by Parliament's Committees and the Council of the European Union, as on the issue there are not available documents by these subject yet.

120 And with references also in the proposed article 13f.4(d), as we are going to point out in the next sub-paragraph. 
posed article 162a, empowering the Commission to update the list of company forms in Annexes I, II and IIA. ${ }^{121}$

\subsection{GENERAL PROVISIONS}

The new articles 13a to 13e are a sort of a set of general rules on digitalization. Already here we can find hints of the principles we have already seen in the SDGP.

Starting from the equivalency between domestic citizens and European foreigners, we find it very clear already in the proposed article 13b, regarding recognition of identification means to be used in online procedures. In it, a clear reference to the e-IDAS Regulation is present too; all of this traces back to the already mentioned SUP Draft Proposal, ${ }^{122}$ issued in April 2014 by the Commission in order to suggest the creation of a harmonized legal environment for the registration of single-member companies. ${ }^{123}$ In its last available version

121 Besides that, there are in the Proposal also a few "housekeeping issues" dealing with technical adjustments to the Codified Directive on:

- the business register interconnection system, allowing the creation of new optional access points by the Commission or the Member States in order to take full advantage of the system, and establishing new technical requirements and specifications (proposed amendments to articles 22 and 24);

- the repeal of the Contact Committee laid down by article 43, and currently without a legal basis;

- the simplification of provisions laid down in current version of article 16 by splitting it into a new article 16 and an article 16 .

122 See above, ref. 7.

123 In literature, there are many comments to the different versions of the proposal; we can mention here the most relevant to our purposes.

On the original version: Conac, P.H.: The Societas Unius Personae (SUP): A "Passport" for Job Creation and Growth, European Company and Financial Law Review, 2015, p. 139; Hansen, J.L.: The SUP Proposal: Registration and Capital (Articles 13-17), European Company and Financial Law Review, 2015, p. 177; Malberti, C.: The relationship between the Societas Unius Personae proposal and the acquis: Creeping Toward an Abrogation of EU Company Law?, European Company and Financial Law Review, 2015, p. 238; Wuisman, I.: The Societas Unius Personae (SUP), European Company Law, 2015, p. 40; Teichmann, C. and Fröhlich, A.: Societas Unius Personae (SUP): Facilitating Cross-Border Establishment, Maastricht journal of European and comparative law, 3, 2014, p. 536; Esteban Velasco, G.: La propuesta de Directiva sobre la "Societas unius personae" (SUP): las cuestiones más polémicas, El notario del siglo XXI: revista del Colegio Notarial de Madrid, 2015, p. 148; Id.: La propuesta de Directiva relativa a las sociedades unipersonales de responsabilidad limitada (en especial la Societas Unius Personae), in: Rojo Fernández-Río and Campuzano Laguillo (eds.): Estudios jurídicos en memoria del profesor Emilio Beltrán, Vol. 1, Valencia, 2015, p. 909; Lucini Mateo, A.: En torno al Proyecto de Directiva europea sobre la Sociedad Limitada Unipersonal (SUP) presentado 
before the withdrawal by the Commission due to lack of political consensus, ${ }^{124}$ the issue of the identification of the founding member was at large dealt with as it is now in the Proposal on digitalization. ${ }^{125}$

\subsubsection{THE IDENTIFICATION OF EUROPEAN CITIZENS (E-IDAS REGULATION AND DIGITALIZATION PROPOSAL)}

While in the SUP Draft Proposal the issue of identification was treated just with reference to the single funding member or his/her representatives, in the Digitalization Proposal it is applicable to all those subjects whose action could take place upon registration of the company and online filing. In spite of this, the underlying principles are the same in the two documents. The general idea is that the identification of a European Citizen should take place without the physical presence of such person before authorities of the same or another Member State, unless there is a "genuine suspicion of fraud based on reasonable grounds". 126

por la Comisión Europea el 9 de abril de 2014, La Ley mercantil, 10 (enero), 2015, p. 24; Id.: El proyecto de Directiva Europea acerca de la Sociedad Limitada Unipersonal, El notario del siglo XXI: revista del Colegio Notarial de Madrid, 2015, 61, p. 54; Lecourt, B.: La Societas Unius Personae: la nouvelle société unipersonnelle à responsabilité limitée proposée par la Commission européenne, Revue des sociétés, 2014, p. 699; Serra, C.: Societas Unius Personae (SUP) - Um Golem na União Europeia?, Direito das sociedades em revista, 2014, p. 127.

On the General Agreement version: Jung, S.: Societas Unius Personae (SUP) - The New Corporate Element in Company Groups, European Business Law Review, 2015, p. 645; Esteban Velasco, G.: La Propuesta de Directiva sobre la "Societas Unius Personae" (SUP): el nuevo texto del Consejo de 28 de mayo de 2015, Anales de la Academia Matritense del Notariado, 2015, p. 105; Bartolacelli, A.: La Societas Unius Personae (SUP): verso un nuovo modello societario unipersonale europeo?, Le nuove leggi civili commentate, 2016, p. 601; Fuentes Naharro, M.: Una primera aproximación al test de solvencia recogido en la propuesta de directiva sobre la Societas Unius Personae (SUP), working paper [http://www.ucm.es/eprints], accessed on 13/08/2018; Teichmann, C. and Götz, A.: How to make a Molehill out of a Mountain: The Single-Member Company (SUP) Proposal after Negotiations in the Council, in: Viera González, A.J. and Teichmann, C. (eds.); Private Companies in Europe: the Societas Unius Personae and the Recent Developments in the EU Member States, Cizur Menor, 2016, p. 29. The entire just cited book contains many papers dealing with the issue here in discussion.

124 Officially on July $4^{\text {th }}, 2018$ with document 2018/C 233/05; the withdrawal had already been anticipated by a Communication of the Commission of October $24^{\text {th }}, 2017$, COM (2017) 650 final, [https://ec.europa.eu/info/sites/info/files/cwp_2018_annex_iv_en.pdf], accessed on 13/08/2018, n. 10.

125 And we are going to see in a while as the same core subject of the Proposal on digitalisation, the online registration of companies, comes directly from the SUP Draft Proposal.

126 Digitalisation Proposal, article 13b.4. The provision recalls very closely the SUP Proposal, G.A. version, article 14b.3 and .4, which laid down that the Member State was exceptionally 
In the normal case, i.e. when there is not a suspicion of fraud, the Member State's register shall identify the applicant. As the entire system designed by the Proposal is based on online procedures, such identification will not be carried out through analogic means of identification - for instance, a paper ID card, or a paper Passport issued by a Member State. More precisely, the mentioned means of identification are likely to be used, after their digitalization (e.g.: a scanned copy), if the Member State allows it.

Basically, identification means can belong to two categories: on the one hand, we have, traditional, paper identification means; on the other hand, electronic means. The choice between adopting paper or electronic identification means is made by each Member State; and even if electronic identification means are adopted, the citizen is in any case provided with a paper/hardcopy support of the identification document. The difference is that while traditional paper identification means cannot be read by electronic devices, and do not contain digitalized information, electronic identification means have these two basic features, and in most cases data written in the hardcopy support are available also in encrypted databases kept by Member States. Anyway, not all the electronic identification means are the same.

In order to understand this, it is necessary to introduce the notion of "electronic identification means" used by the Digitalization Proposal and that cross-references the e-IDAS Regulation.

e-IDAS Regulation ${ }^{127}$ is a piece of European legislation issued in 2014 establishing, among the other, the key standards for the mutual recognition of foreign electronic identification means by the Member States. ${ }^{128}$ Member States are free:

a) to adopt just paper-based means of identification;

b) to adopt (only or in addition) electronic means of identification, and in this case, such means of identification can be:

b.1) compliant with e-IDAS Regulation, if they follow the e-IDAS standards (and in this case there is the automatic mutual recognition of foreign means of identification);

\footnotetext{
free to require the presence of the person to be identified before its national authorities in case of a genuine suspicion of fraud. In the SUP Proposal this was the only case in which the registration could occur not fully online.

Besides this exception, another one can be established by Member States regarding the registration of companies where the shareholders have made in-kind contributions: see article 13f.4(f) and more in detail below, subparagraph 5.3.1.

127 Details above, ref. 8 .

128 The entire subject is very technical, and perhaps for this reason there are not academic commentaries on the e-IDAS Regulation.
} 
b.2) not compliant with e-IDAS Regulation (without automatic mutual recognition).

The basic principle is that the Member States are free to decide whether adopts e-IDAS standards, or not. ${ }^{129}$ Thus, there is nothing preventing Member States from maintaining just the paper-based identification system, apart from the lower degree of competitiveness of such State (or, more correctly, of such State's national citizens) in a globalized and increasingly always more digitalized market. The enforcement to the creation of electronic identification schemes, their notification to the Commission, and consequently their compliance with e-IDAS Regulation is only indirect. ${ }^{130}$ And, even if the European institutions provide for minimum technical standards to comply with regarding data security, not all the Member States are going to issue electronic identification means with the same level of assurance. ${ }^{131}$ It is even possible that

129 According to the e-IDAS Regulation, article 2, the "Regulation applies to electronic identification schemes that have been notified by a Member State, and to trust service providers that are established in the Union". This notification is dealt with by subsequent article 9. In general, this means that when a Member State establishes an electronic identification scheme - "a system for electronic identification under which electronic identification means are issued to natural or legal persons, or natural persons representing legal persons": article 3(4) - it is free either to notify it to the European Union, or not. In the latter case, the electronid identification means issued under such scheme won't be e-IDAS compliant.

130 Each Member State can establish one or more identification schemes that not necessairly will be managed by public authorities.

131 What is relevant to the purposes of the e-IDAS Regulation is that the electronic identification means issued under the notified identification scheme must have a certain degree of assurance. Such levels are described in detail by article 8.1 and .2: "1. An electronic identification scheme notified pursuant to Article 9(1) shall specify assurance levels low, substantial and/or high for electronic identification means issued under that scheme.

2. The assurance levels low, substantial and high shall meet respectively the following criteria: (a) assurance level low shall refer to an electronic identification means in the context of an electronic identification scheme, which provides a limited degree of confidence in the claimed or asserted identity of a person, and is characterised with reference to technical specifications, standards and procedures related thereto, including technical controls, the purpose of which is to decrease the risk of misuse or alteration of the identity;

(b) assurance level substantial shall refer to an electronic identification means in the context of an electronic identification scheme, which provides a substantial degree of confidence in the claimed or asserted identity of a person, and is characterised with reference to technical specifications, standards and procedures related thereto, including technical controls, the purpose of which is to decrease substantially the risk of misuse or alteration of the identity;

(c) assurance level high shall refer to an electronic identification means in the context of an electronic identification scheme, which provides a higher degree of confidence in the claimed or asserted identity of a person than electronic identification means with the assurance level substantial, and is characterised with reference to technical specifications, standards and procedures related thereto, including technical controls, the purpose of which is to prevent misuse or alteration of the identity". 
different electronic means issued by the same Member State, under the same identification scheme, have different levels of assurance; besides that, it will be possible that the identification means issued by different Member States have different levels of assurance. This could cause issues on the field of reliability of the information under a cross-border point of view.

Furthermore, cross-border mutual recognition of the electronic identification means needs a common interaction platform; this will be fully operative by September $29^{\text {th }}, 2018 .^{132}$

The mutual recognition system ensured by e-IDAS allows that the information regarding the identification data of the citizens detained by a Member State, and guaranteed in its reliability by the measures taken by the State upon the issue of the identification mean, can be exchanged with another Member State, provided that they are e-IDAS compliant.

The rules regarding such system are laid down in e-IDAS Regulation's article 6. The basic principle is that a Member State (Member State "A") shall automatically recognise the electronic identification means issued by another Member State (Member State "B") when A requires electronic identification for its own national citizens to access a service provided by $\mathrm{A}$, and provided that:

- the electronic identification means issued by $\mathrm{B}$ is listed in the Commission's notification list; and

- B's electronic identification means level of assurance must be equal or higher than A's ones (that has to be no lower than substantial).

This is the general framework for mutual recognition in the e-IDAS Regulation. It is to be coordinated with Digitalization Proposal's article 13b, whose application purposes are both domestic and cross-border.

In order to allow online registration and filing of documents in the national registers, the Member State where the register is located (Member State "A") shall accept:

a) Electronic identification means issued by Member State A itself;

b) Electronic identification means issued by Member States different than A, but recognized by A in accordance with e-IDAS Regulation's article 6;

${ }_{132}$ As of August 2018, almost all European Member States have already implemented at least an electronic identification scheme. According to the Commission's official website on the issue, [https://ec.europa.eu/cefdigital/wiki/display/CEFDIGITAL/Country+Overview+-+eID], accessed on 14/08/2018, only Bulgaria, France, Romania, Poland are still in a phase of implementation, while the notification procedure has been completed by Germany, Croatia, Luxembourg, Estonia, Italy, Spain, Portugal, Belgium. 
c) Other identification means, not necessarily electronic, issued by the Member State A, provided that the same type of identification means issued by other Member States are equally accepted. ${ }^{133}$

Exactly as it happened in the SUP Proposal, G.A. version, ${ }^{134}$ we can see here two different levels of application. On the one hand, recognition of identification means under a) and b) is mandatory for all the Member States, ${ }^{135}$ on the contrary, the recognition under c) is mandatory only with reference to the respect of the principle of equality of treatment of citizens of all the Member States. ${ }^{136}$

This system should allow to check fully online the identity of an applicant; there are nevertheless concerns regarding possible cases of identity fraud; for this reason, the already mentioned provision allowing Member States to require the physical presence of the applicant for the purposes of verifying the identity, "in cases of genuine suspicion of fraud based on reasonable grounds". ${ }^{137}$ Examples of such "reasonable grounds" are offered in the Preamble, ${ }^{138}$ specifying that the requirement of the physical presence is to be intended as exceptional, "not systematically but on a case-by-case basis", "on the basis of information available from the registers of beneficial owners, from criminal records or from indications of identity fraud or tax evasion". 139

The point is that it is not impossible to imagine that Member States not extremely happy with a fully online procedure could use the mentioned exceptional provision as a "picklock" to "demolish" the entire system. From this

133 For instance, a digital/scanned copy of a Passport or ID card is not an electronic identification means, but simply a digital copy of a traditional identification means. If a Member State, for instance, Italy, accepts a scanned copy of an Italian ID card for the purpose to register a company, the Italian register will not be able to refuse the registration to a Danish citizen willing to use for the same purpose a copy of a Danish ID card.

134 Article 14b.

135 Even if issues are likely to arise in case of different levels of assurance of the electronic identification means issued by a different Member State.

136 About the issue of the use of e-IDAS Regulation in the first version of the SUP Directive, with proposals eventually transposed in the G.A. version, see Wuisman, I.: op. cit. in ref. 123, p. 40; Malberti, C.: The Relationship, cit. in ref. 123, p. 266 seq.; Esteban Velasco, G.: La Propuesta de Directiva sobre la "Societas Unius Personae" (SUP): el nuevo texto, cit. in ref. 123, p. 133.

137 Article 13b.4.

138 Whereas 14.

139 These examples SUPplied by the Whereas 14 are very meaningful, in particular because the SUP Proposal, G.A. version did not require "reasonable grounds", and consequently did not SUPply any kind of examples for such grounds, for the exceptional case of the required physical presence of the applicant. 
point of view, it seems very relevant that the Preamble states examples of the "reasonable grounds". We must however note that the notion of "reasonable" is extremely subjective; for this reason, it seems that the Member States barely could find themselves bound by this kind of reasonableness.

Furthermore, the examples supplied in the Preamble do not actually seem to be a-systematic. On the contrary, they set some kind of supposition, which for its own nature is systematic, assuming that when an applicant had issues with identity fraud or tax evasion this would be enough to get rid of the online system, applying the traditional one. It seems that this issue should be carefully revised. ${ }^{140}$

\subsubsection{INFORMATION}

The second similarity we can find between the SDGP and the Digitalization Proposal deals with the information to supply regarding each Member State's Company Law system, according to proposed article $13 \mathrm{e} .{ }^{141}$ This is evidently in order to allow interested people to have an idea of Member State's Company Law, even if the belief that the information mentioned in article 13e is sufficient to have a conscious awareness regarding the basic structure of companies in the Country where one is intending to invest is more than naïve.

The spread of information is, as we have already seen, one of the key issues of the SDGP; for this reason, the interlocking between these two Proposals finds here its strong ring: Member States have to provide the information on Company Law on the same websites used to upload information to the Single Digital Gateway. This rule allows completing the information to be supplied by the Single Digital Gateway with the provisions on Company Law as well.

Nevertheless, the structure of article 13e clearly exposes the actual purposes of the information to provide. In fact, there are two different scopes of information: the first, with a narrower range of details, regarding all the company forms allowed under domestic law (those listed in Annex II of the Codified Directive) $;{ }^{142}$ and a second, whose application is limited to the companies list-

\footnotetext{
140 Actually, the Impact Assessment, p. 45 seqq. informs that several options had been taken in consideration, and the one including the exceptional possibility described in the text was deemed as the preferred for its being "highly cost-effective for companies while offering the highest protection for stakeholders" (p. 49).

${ }_{141}$ A similar provision, dealing with the basic profiles on the functioning and registration of the company were present also in the SUP Proposal, G.A. version, article 12.

142 Pursuant article 13, even according the proposed new text. The information to provide are, according to the proposed article 13e.1:
} 
ed in the proposed new Annex IIA - i.e. private companies - that is by far more extended. ${ }^{143}$ Furthermore, the latter is explicitly said to contain just the minimum information, leaving by this way the Member States free to provide additional information.

By reading the latter list of required information, it is very clear that the ultimate purpose of the Commission in drafting the rule is to provide possible investors in SMEs abroad with a sort of "certified vade mecum" of applicable rules.

\subsubsection{REMAINING GENERAL PROVISIONS}

The remaining provisions we can find in the General Part of the Proposal on Digitalization deal with not strictly digital issues, which are nevertheless useful to guarantee an actual implementation to the substantial rules. Articles

"(a) requirements concerning the registration and operation of companies and their branches, including online registration and online filing under national law;

(b) requirements relating to the use of templates, including information on national laws which govern the use and contents of such templates;

(c) requirements relating to the authentication of documents and information to be submitted as part of the online registration procedure;

(d) rules relating to the means of identification required as part of the online registration and filing."

143 New article 13e.2: “(a) any formalities relating to online registration of and online filing by a company or branch, including procedures and time limits, together with details of all documents and information required and any applicable fees;

(b) any requirements concering the submission of documents drawn up in other languages, including the translation or certification of such documents;

(c) the means of identification, as referred to in Article 13b, required by the Member State;

(d) the powers and responsibilities of the administrative body, the managerial body and the SUPervisory organ of the company or branch including the representation of a company or a branch towards third parties;

(e) the requirements for becoming a member of the administrative body, the managerial body and the SUPervisory organ of the company or branch;

(f) details concerning the decision-making process of the administrative body, the managerial body and the SUPervisory organ of the company or branch;

(g) details relating to the rights and obligations of the shareholders;

(h) details concerning the payment of dividends and other forms of distributions;

(i) information relating to legal reserves, where applicable;

(j) conditions affecting the validity of pre-incorporation contracts;

(k) any requirements relating to the operation and activities of a branch by a company, as well as any requirements relating to the opening and closure of a branch;

(1) any requirements relating to a change in the documents and information referred to in $\mathrm{Ar}-$ ticles 14 and 30". 
$13 \mathrm{c}$ and 13d, in fact, lay dawn the rules on, respectively, applicable fees for online registration and filing, and means of payment. In both of the cases, the underlying principle is the equal treatment of domestic and cross-border situations. ${ }^{144}$

Thus, there shall be no discrimination (for citizens of the Member State of registration and citizens of other Member States) in the fees applicable to the register and the filing, and the fees "shall not exceed the administrative costs of providing the service". And, as far as payments are concerned, if the procedure implies the payment, for instance, of a fee, such payment shall be possible "by means of a payment service widely available in cross-border payment services". 145

\subsection{ONLINE REGISTRATION AND FILING OF COMPANIES AND BRANCHES}

The core part of the Digitalization Proposal deals with the online registration of companies, and with the online filing of documents; these issues cover the area of branches too, but certainly the "main course" of the proposal deals primarily with companies. It is not surprising, thus, that the rules on branches in practice simply reply those previously set down for the companies.

Again, the issue of online registration was the key feature of the SUP Propos$\mathrm{al}$; and so evidently the key feature, to lead some commentators to argue that preparing a legal framework suitable for registering companies online was, in reality, the sole, hidden, purpose of that Proposal. ${ }^{146}$ By requiring that the Member States had to ensure that the online registration of the SUP had to be possible, the Commission was, in fact, indirectly imposing them an extremely costly obligation, which would have been completely senseless to limit to the economically almost irrelevant Societas Unius Personae. As the system would have been prepared for the $S U P$ - this was the unavowed belief of the

\footnotetext{
144 As the ICLEG Report advocates for too, at p. 16 seq.

145 The necessity of such last provision seems to be questionable; as we have already seen, provisions in the same sense are already present in the current version of the Codified Directive (namely at article 24(k)): see also above, ref. 83.

146 Siems, M.: The Societas Unius Personae (SUP): a Trojan Horse?, [siemslegal.blogspot. it/2014/04/the-societas-unius-personae-SUP-trojan.htm], accessed on 13/08/2018; Hansen, J.L.: The SUP Proposal, cit. in ref. 123, pp. 178, 180 seq. and 189 seq.; Schmidt, J.: Der Vorschlag für eine Societas Unius Personae (SUP) - SUPer oder suboptimal?, GmbH-Rundschau, 2014, 9, p. 130; Esteban Velasco, G.: La Propuesta de Directiva sobre la "Societas Unius Personae" (SUP): el nuevo texto, cit. in ref. 123, p. 131, footnote 45; and Bartolacelli, A.: La Societas Unius Personae, cit. in ref. 123, p. 610 seq.
} 
Commission - the Member States would eventually have it extended to all the company forms. Unfortunately, or fortunately, the SUP project did not succeed. Exactly at that point, the idea for a Proposal on Digitalization come out; by this way confirming that the real purpose of the $S U P$ was what we can find now as the core issue of the Digitalization Proposal: the online registration of every company form. ${ }^{147}$

\subsubsection{ONLINE REGISTRATION OF COMPANIES}

The rules on online registration of a company are contained in proposed articles $13 \mathrm{f}$ and $13 \mathrm{~g}$.

The basic idea is that Member States have to ensure the fully online procedure of registration of a company for at least private companies. Honestly speaking, the wording of the rule is nonetheless questionable: the general rule is that a fully online registration must be available for (all of the) companies; however, "Member States may decide not to provide fully online registration procedures for those types of companies listed in Annex I". ${ }^{148}$

This means that once that a Member State decides to exclude the companies listed in in the Annex I from the possibility of being registered online, all the remaining company types present in Annex II, apart from those listed in Annex I, shall take advantage of the possibility of an online registration. Companies listed in Annex I are public companies, for instance Aktiegesellschaft in Germany, or Società per azioni in Italy, or Société anonyme in France. According to article 13 , however, article $13 \mathrm{f}$ is applicable to all the company forms listed in Annex II; this means, using the same Member States just cited, Aktiengesellschaft, Kommanditgesellschaft auf Aktien, Gesellschaft mit beschränkter Haftung for Germany, società per azioni, società in accomandita per azioni e società a responsabilità limitata for Italy, and société anonyme, société en commandite par actions, société à responsabilité limitée, société par actions simplifiée for France. If we deduct the content of Annex I from Annex II, the result - i.e. the mandatory scope of application of the possibility for an online registration - is not limited to private companies (that are listed on the contrary in the proposed Annex IIA): there are the Kommandit, accomandita, commandite - limited partnerships by shares - for those Member States that have such company form. Due to the specificities of such company forms, it

147 The same approach was adopted by the ICLEG Report, p. 17, with the proposal to extend the online formation to all the company types covered by the late Directive 2009/101, i.e. those currently listed in Annex II of the Codified Directive.

148 Proposed article 13f.1. 
makes no sense to have a mandatory online registration scheme for them too. Their inclusion in the scope of mandatory application of article $13 \mathrm{f}$ seems due to a slip of the pen, rather than a conscious choice. ${ }^{149}$ On the contrary, it would be much better to allow Member States to limit the scope of application of article $13 \mathrm{f}$ just to company forms listed in the proposed Annex IIA.

The fact that the Member States have to ensure the possibility of a fully online registration of companies pursuant proposed article $13 \mathrm{f}$ does not mean that they must have it as the sole means of registration; on the contrary, the online registration is to be intended as an option. The founders will be free to choose between the traditional, paper-based registration, and the online registration, at least for those company forms for which the Member States have to ensure the implementation of such digital tool.

Again, the process of registration will be completed online only provided that the "genuine suspicion of fraud based on reasonable grounds" already analyzed under new article 13b.4 does not exist.

Due also to the nature of Directive of the proposed piece of legislation, besides the respect for "Member States' existing traditions of company law", ${ }^{150}$ the Proposal does not set down rules for online registration directly; on the contrary, such duty belongs to the Member States. The Proposal, however, establishes the scope of such rules, prescribing that they must include details on the use of templates and "the documents and information required for registering a company". ${ }^{151}$ Regarding this latter specification, the Member States have to ensure that information and documents can be submitted electronically and in particular that authenticated electronic copies issued by other Member States' registers and compliant with the e-IDAS Regulation are accepted.

Even if the Member States are theoretically free to set their own rules on companies' registration, the Proposal lays down provisions regarding the minimum

\footnotetext{
149 This even more if we consider the reason for the possible derogation for the companies listed in Annex I: "due to the complexity of establishment and registration of such companies and in order to respect Member States' existing traditions of company law": Whereas 9. Now, the limited partnerships by shares have in common with public limited companies (Annex I) the same complexity of establishment and registration, even increased by the necessary presence of at least to categories of shareholders, one even with unlimited liability.

Besides the Member States mentioned in the text, the same issue is present in Belgium, Denmark, Spain, Poland, Portugal, Romania, and Slovenia.

150 Again, Whereas 9 and 12. This specific provision deals in particular with the need, in many Member States, of the intervention of a notary in the process of registration; the subject will be analysed in a while.

151 Proposed article 13f.2.
} 
scope of such rules, ${ }^{152}$ and further optional content. ${ }^{153}$ This distinction is likely to create issues, though. In fact, if the Proposal states the minimum mandatory content ("The rules [...] shall at least provide for the following...") first, and immediately after adds the optional one ("The rules [...[ may also provide for the following"), the question arises whether Member States are entitled to add further rules besides those listed in 13f.4, or not. If the answer is negative, the very nature of the Proposal as actually a Directive seems to be in peril.

Coming to the content of the rules on online registration that the Member States may or could implement, the mandatory ones deal with procedures to ensure:

- The legal capacity of the applicant and their authority to represent the company;

- That the person registering the company is actually the person that claims to be (verification of identity);

- How the applicant can use the trust services referred to in e-IDAS regulation, mainly for the purposes of authenticating documents.

The optional content, on the other hand, refers to:

- How to ensure the legality of the object of the company;

- How to ensure the legality of the company's name;

- How to ensure that the instrument of constitution - and/or the filling-in of the template, if used - is compliant with the law;

- How to verify the appointment of the directors, "taking into account the disqualification of directors by competent authorities of other Member States";

- How to ensure the presence of a notary or other person of body within the procedure of online registration, if so required by Member State's law;

- An additional case of impossibility to complete the online procedure of registration, due to the presence of shareholders' contributions in kind.

These rules are the starting point for a series of brief remarks.

With reference to the mandatory provision on the identity check, we must note that there is a meaningful step forward, if compared with the SUP Proposal, even in its G.A. version. In fact, in that Proposal the control on identification was simply optional: "the process of registration, including possible control of

152 Proposed article 13f.3.

153 Proposed article 13f.4. 
legality that may consist of verification of identity and legal capacity (...)". ${ }^{154}$ This development is likely to be due to the implementation of the e-IDAS Regulation, which had not been approved yet as of the first version of the SUP Proposal. Furthermore, the compulsory check of the applicant's legal capacity seems a good achievement too, as a good means to ensure the lawful constitution of the company also from the subjective perspective. ${ }^{155}$

As for the optional rules referred to in article 13f.4, their being not mandatory is due to the fact that they deal with issues not necessarily present every Company Law tradition. We have in fact cases in Europe where, for instance, company's object are not to be disclosed in a mandatory way; or a company's name is to be chosen from a pre-approved list; or, again, the notary or other public functionaries are not playing a role upon a company's registration.

The role of notaries is one of the Proposal's critic points. In order to understand the caution used by the Commission in dealing with such issue, we must remember that this subject caused the final deadlock in the SUP Proposal. We can deal with it along with the theme of templates.

Following some sort of a "tradition" in the last proposals in the area of Company Law, ${ }^{156}$ the Proposal mentions templates for the registration of companies the Member States have to make available. ${ }^{157}$ Regarding this issue too, Member States face on the one hand an obligation, and on the other hand are given an option. The obligation to make available templates for the registration is lim-

154 SUP Proposal, G.A. version, article 14a.1. The italicisation is mine. In the same sense also the Whereas 18 . The freedom regarding such verification was correctly criticised by Teichmann C. and Fröhlich A.: Societas Unius Personae, cit. in ref. 123, p. 542 seq.

155 As it is useful remind that according to Codified Directive, article 11(b)(v) the incapacity of founding member is likely to lead to the nullity of the company, under many jurisdictions.

156 Templates were present in the SPE Proposal of Regulation on a European Private Company: Proposal for a Council Regulation on the Statute for a European private company, of 25 June 2008, SEC (2008) 2098; SEC (2008) 2099, [https://eur-lex.europa.eu/legal-content/ EN/TXT/?uri=COM:2008:0396:FIN], accessed on 15/08/2018, now withdrawn (since 21 May 2014). The suggestion to use templates was present since the proposal of compromise of April 2009. Regarding the issue, in general, see: Guidotti, R.: The European Private Company: The Current Situation, German Law Journal, 2012, p. 331.

Eventually, templates have been one of the hallmarks of the SUP Proposal, with different attitudes regarding their source in the considered versions. At the very beginning, in the original version, the templates had to be prepared by the Commission itself (article 11.3); while in the G.A. version this duty was pending over the Member States (articles 11.4 and 13.3). This solution appears to be the most effective, due to the issue that a centralised drafting are likely to cause due to the diverging national provisions in the subject. Accordingly, on the SUP Proposal, Malberti, C.: op. cit. in ref. 123, p. 258, footnote 73.

157 Such issue was faced also by the ICLEG Report, p. 18, advocating for standard articles to be prepared by the Member States. 
ited to the company forms listed in Annex IIA; while for the other company types listed in Annex II (public companies and limited partnerships by shares) they simply "may also make templates available". ${ }^{158}$ Such approach reassesses, once again, that the main recipient for the interventions the Digitalization Proposal deals with are SMEs established in form of a private company.

The content of the template is to be defined freely by each Member State; ${ }^{159}$ and the Member States are to make available the templates - each one of them, both the mandatory and the optional ones, if any - on the Single Digital Gateway portal. Consistently with the SDGP's rules, the templates too are to be made available "at least (...) in an official Union language broadly understood by the largest possible number of cross-border users"160; this naturally besides the Member State's official language.

The templates may have two functions, according to the domestic applicable law. On the one hand, they can be used simply as forms for the registration in the online portal serving to that purpose; on the other hand, they can also be where domestic Company Law allows it, the very instrument of incorporation of the new-born company. ${ }^{161}$

The templates deal with the role of notaries upon a company's incorporation primarily because in the Member States with notarized incorporation of companies the notaries are usually in charge of drafting the company's instrument of incorporation, comprising their charters or articles. Naturally, the fact that templates are available for such a purpose is by itself perceived by notaries as some kind of a threat to their role in companies' incorporation: "if templates for articles are available, what are we supposed to do?" is the logic question. ${ }^{162}$ As on this issue - among the others - the SUP Proposal was wrecked, the European Commission was much more careful in the drafting of the Digitalized Proposal regarding this specific subject. ${ }^{163}$

\footnotetext{
158 Proposed article 13g.1.

159 Proposed article 13g.4. This is a meaningful change if compared with the system draft in the SUP proposal, even in its G.A. version, where the European lawmaker set down a maximum content for such document, with a provision rightly criticised by Esteban Velasco, G.: La Propuesta de Directiva sobre la "Societas Unius Personae" (SUP): el nuevo texto, cit. In ref. 123, p. 120.

160 Proposed article 13g.3.

161 Here we can find another divergence, if compared with the SUP Proposal's rules, where, at least in the original version, two separate templates were mentioned, one for the registration, and one for the instrument of incorporation (see: article 11.3, original version).

162 And such question is present in the Impact Assessment as well, p. 17 seq.

163 In the original SUP Proposal, there was no explicit mention of the role of notaries as of a company's registration (apart from the Impact Assessment annex to the Proposal), even if
} 
The notaries, as in the withdrawn SUP project, as in the current Proposal, maintain in any case, where present according the applicable domestic law, the verification of the identity and the legal capacity of the people involved in the registration process, and of the legality of the instrument of constitution, "including verifying the correct use of the templates". ${ }^{164}$

Now, it is now clear why the (optional) provision on the role "of a notary or other person or body mandated by the Member State", i.e. proposed article 13f.4(e), is to be read together with the mandatory rules of proposed article 13f.3(a) and (b), and the optional ones of proposed article 13f.4(a), (b), (c), (f), and partly (d) ${ }^{165}$ We can thus say that the latterly mentioned rules are held as optional by the Proposal because it deals with them from a general perspective; they have on the contrary to be intended as mandatory for those Member States where the notaries have a role in a company's registration. This should help notaries in being more in favor of the Proposal than they were in occasion of the discussion about the SUP. The notarial role, anyway, must find place in the fully online procedure, and this can be realized for instance by means of a video-conference system..$^{166}$

Consistently with such reading of the proposed norm, thus, the provision stating that "Where those templates are used by the applicant in compliance with the rules referred to in point (c) of Article 13f(4), where applicable, the requirement to have the company instruments of constitution drawn up and certified in due legal form as laid down in Article 10 shall be deemed to be fulfilled" 167 is not

\footnotetext{
the domestic Company Law of many Member State recognises it. This fact comprehensibly provoked a certain degree of annoyance in Europe's notaries, which were afraid that the SUP Proposal was a measure to tone down, in an indirect way, their function in Company Law. For this reason, during the lifespan of such Proposal mentions to notaries' role were added (for instance, in the G.A. version see article 14b, and Whereas 13, 13a, 18 and 18a of the Preamble), even if according to some scholars the notarial role was in any case preserved already in the original version. See Hansen, J.L.: op. citi in ref. 123, p. 179; however, the majority of commentator was critical about that: Lucini Mateo, A.: En torno al Proyecto, cit. in ref. 123, p. 4; Ries, P.: Societas Unius Persononae - cui bono?, NZG - Neue Zeitschrift für Gesellschaftsrecht, 2014, p. 569. And see also the Impact Assessment to the Proposal on digitalisation (SWD(2018) 141 final, of 25.4.2018), p. 17 seq.

164 Proposed article 13f.4(c).

165 Just partly, as for the letter (d), as this provision seems to require additional rules in domestic law in order to be made applicable; see more in detail below, paragraph 5.4.1. In any case, there is no doubt that, where a notary is present, the verification of the lawful appointment of directors is a duty impending over him.

166 As proposed in the Impact Assessment to the Proposal, p. 48, and admitted in general terms in the ICLEG Report, p. 19.

167 Proposed article 13g.2.
} 
surprising at all. The "due legal form" is in any case respected, also for the Member States where notarial role is required, by virtue of the just discussed rules.

A further common duty of notaries, in many domestic Company Laws, is to check that the part of the share capital required by national law to be paid down upon constitution has actually been paid. This leads to the type of contributions that the shareholders could provide the new company with. The rules on the issue are extremely different country by country, in particular as the Proposal is mainly addressed to private companies, where the boundaries set down by articles 46 seqq. of the Codified Directive are not applicable. For this reason, the Proposal on Digitalization only offers (scanty) provisions on cash and in-kind contributions.

As for cash, the Proposal reassesses the principle of the possibility to make the payment through online tools, having as a beneficiary a bank account in a bank operating generically in the Union. Furthermore, Member States shall have the duty to ensure that the proof of payment too can be provided online. ${ }^{168}$

Regarding in-kind contributions, the Proposal only mentions it in two passages, whose combination shows that the ultimate decision regarding the consent on allowing such kind of considerations even in presence of an online registration is left to Member States. We must consider, in fact, that in many jurisdictions in-kind contributions require experts' reports to assess the actual value of the consideration. Such a requirement is likely to complicate the online registration process, even if it is not by itself preventing it at all. Member States are thus offered two options.

The fact that one or more shareholders decide to make in-kind contributions, provided that they are allowed by company's article, could be a ground for the Member State to refuse the online registration, if a specific provision exists in national Company Law. Such a provision is explicitly held as lawful by the Proposal, as we have already pointed out. ${ }^{169}$

On the other hand, the equally lawful provision by a Member State allowing shareholders' in-kind contributions is confirmed not just by the wording of the just mentioned rule; ${ }^{170}$ but also by subsequent paragraph 7 on the maximum time allowed for the completion of the online registration.

168 Proposed article 13f.6, consistently with article 13d. Regarding this issue, it should be carefully examined the compatibility of such means of payment with those systems (for instance, the Italian and the Portuguese one for their private companies) that allow or prescribe the payment to be made directly in directors' hands.

169 Proposed article 13f.4(f).

170 "The circumstances in which online registration may be excluded where the share capital of a company is to be paid by way of contributions in kind"; italicisation is mine. This means 
The entire issue of online registration, together with the rules on templates, is motivated on the grounds of the need to complete the registration process in a quicker, less expensive and cross-border available way. ${ }^{171}$ For this reason, the key rule regarding the process of online registration is that Member States have to ensure that the registration process, where carried out online, is completed within five working days from either the receipt by the register of all the documents required for the registration, or the payment of fees or share capital according to national law, depending on the last performed. ${ }^{172}$

Especially the check regarding the fact that the share capital has been paid up has to be performed by a notary, if any, pursuant the national applicable law, along with the assessment that the prescribed licenses or authorizations for the registration of the company had been obtained. ${ }^{173}$

\subsubsection{ONLINE REGISTRATION OF BRANCHES}

While the online registration of a company was not completely new among the Commission's proposals in the field of Company Law, the document on Digitalization marks the first time that the issue is dealt with regarding branches.

Actually, the introduction of rules on online registration of branches in the analyzed Proposal makes perfectly sense. This not only because of the electronic nature of the registration; but also as the online registration of a company, supported by the side-provisions we have already at least in part analyzed, allows a cross-border creation of subsidiaries by already existing companies. ${ }^{174}$

that the Member State's provisions could even exclude the online registration just where some types of in-kind contributions are provided, allowing it in presence of other, different in-kind contribution. And, as specific rules about that are missing, work or service contributions seems to be considered as in-kind ones.

171 That is properly the ultimate purpose declared by the Commission: see also the Impact Assessment, p. 16, and its Annex IX.

172 Any "exceptional" derogation from the five days must be "immediately notified" to the applicant, along with the communication of the reasons for the delay: proposed article 13f.7.

173 Such licenses or authorisations must in any case be exceptional, as the Member States are allowed to require the mas needed for the registration just where "it is indispensable for the proper control of certain activities laid down in national law": proposed article 13f.5. An analogous provision was set down in the SUP Proposal, G.A. version, article 14a.3, with the explicit distinction between authorisations needed before the registration, which can be required only exceptionally; and after the registration, before commencing the business. In the latter case, not provided for by the Digitalisation Proposal in an explicit way, but in my opinion plainly applicable to this case too, the Member States are free to ask for the requirements the judge appropriate.

174 We can read accordingly the provision of proposed article $13 \mathrm{f} .2$ where mentioning the electronic copies of documents and information referred to in article 16a.4, which comprehend 
Having specific rules regarding branches as well, allows to have the traditional couple "branches and subsidiaries" reassembled, as far as online registration is concerned too.

The rules on online registration of branches are at large following those on online registration of companies, even if there is here a specific - and welcome - reprise of the last principle we found in the SDGP, the "once-only".

As it is for companies, for branches too Member States have to ensure the possibility of a fully online registration, with the only exception of the "genuine suspicion of fraud based on reasonable grounds". ${ }^{175}$

For the online registration of branches, there is no reference to templates and the article 28a.2 and .3 only lays down mandatory rules to be adopted by the Member States, avoiding the optional ones. ${ }^{176}$ These rules must include norms on the documents and information to submit - including the reference to the electronic copies referred to by proposed article 16a.4, as present in the online registration of companies too - and adds a paramount provision. In fact, we can find here the statement that such rules must ensure that the registration of the branch may be carried out "by making use of the information or documents previously submitted to a register"; 177 mentioning generically "a" register, this means not just the register of the Member State where the branch is about to be registered. ${ }^{178}$ On the contrary, any European register could serve to such purpose, and in particular that where the company establishing the branch is registered. Such rule is the tangible outcome of the register interconnection system: it allows an effective flow of information between the register, with a full advantage of citizens and businesses, which will not be obliged to submit the same document to more than one register anymore. ${ }^{179}$ This is the application of the once-only principle in Company Law, after its announcement in

the extracts of deeds of incorporation of companies registered in different Member States, necessary as means of identification of such companies as the shareholders of the new subsidiary. That was the (declared) purpose of the SUP Proposal, and in this sense we can say once more that the Digitalisation Proposal is some kind of a daughter of such project.

175 Proposed article 28a.1.

176 Such an approach is due to the fact that, as we have already seen, the optional rules for online registration of companies are to be used by Member States where there is the need to preserve the role of the notary. On the contrary, when establishing branches abroad, even if present, the role of the notary is by far less pervasive.

177 Proposed article 28a.2.

178 As in the case of a branch established by a company in its own Member State of registration.

179 This works for the verification on the company establishing the branch as well, according to the proposed article 28a.4. 
the SDGP. And an application of the same principle is also the provision laid down in paragraph 6, establishing an information flow between the register of the company and that of the branch, where different. In particular, the latter must inform the former of the registration of the branch, and the former must accept such information, acknowledging receipt of notification, and recording the information, immediately. In this case, again, this is possible by virtue of the business register interconnection system, and does not require any duplication of informative duties on the company.

Alike it happens with online registration of companies, the rules the Member States have to enact must include procedures for the verification of the identity and the legal capacity of the applicants ${ }^{180}$ and the prohibition to obstacle the registration of a branch by requiring licenses or authorizations unless it is indispensable for controlling certain activities. And, alike it happens for companies, the online process of registration of a branch must be completed within five days from the receipt by the register, or other subject mandated by the State, of all the required documents or information.

\subsubsection{ONLINE FILING BY COMPANIES AND FOR BRANCHES}

Apart from online registration, the Digitalization Proposal deals also with the subsequent filing a company or a branch must perform in the registers. Such issue was already present in the Codified Directive, namely in article 16.3, second subparagraph. ${ }^{181}$ As the issue is of paramount importance for the digitalization in European companies, the original rule was somehow "exploded" in the more detailed regulation we are going to describe.

The basic structure of the provision is the same for companies and branches. The Member States must ensure the possibility of filing entirely online in the register company's and branch's documents and information, ${ }^{182}$ with no need of physical presence of the applicant, apart from the already mentioned

\footnotetext{
180 Proposed article 28a.3.

181 "Member States shall ensure that the filing by companies, as well as by other persons and bodies required to make or assist in making notifications, of all documents and particulars which are required to be disclosed pursuant to Article 14 is possible by electronic means. In addition, Member States may require all, or certain categories of, companies to file all, or certain types of, such documents and particulars by electronic means"; the provision has now been deleted in the proposed version of the article 16. See below, paragraph 5.4.2.

182 The Member States must ensure this possibility, which is only an option, at least in general. Nevertheless, according to proposed article 13i.2, Member States are free to require the online filing as an obligation for some or all the companies registered in their register.
} 
exception for genuine suspicion of fraud. ${ }^{183}$ In this case, as for the timing, no specific provision is present, apart from the mention of the fact that the online filing must be done "within the time limit/period provided by the laws of the Member State where the company/branch is [to be] registered/established". ${ }^{84}$

Only for the companies there is the additional explicit rule regarding the need that Member States ensure that origin and integrity of the filed documents may be verified by electronic means; it seems reasonable that the same rule is applicable to branches, too. ${ }^{185}$

Finally, it is worth mentioning that, with reference to companies, the proposed article 13i.1 mentions the filing of "documents and information, as referred to in article 14" of the Codified Directive. Article 14 in effect lists a series of documents and information to disclose, but leaves Member States free to add more: ${ }^{186}$ the reference to article 14 seems to be interpreted as including in the possible object of online filing also the additional documents and information a Member State decided to add to the list of the Codified Directive. This is in order to prevent inequalities in the application of the rule.

\subsubsection{ADDITIONAL PROVISIONS ON BRANCHES}

Proposed articles 28c, 30a, and a new proposed subparagraph for article 31 provide for a few additional provisions on branches, consistent with some of the principles we already came across.

The first rule deals with the reverse of the online registration of a branch, i.e. the information flow between the register where the branch is filed to the register where the company is registered regarding the closure of the branch. This must take place through the system of interconnection of the registers, exactly alike it is as of the branch's registration, and alike in that case it is an expression of the "once-only" principle. ${ }^{187}$

\footnotetext{
183 Proposed articles 13i.1 and 28b.

184 Ibidem. Just a short remark on two issues. On the one hand, the proposed article 13i mentions the laws of the State where the company is "to be" registered. As here we are dealing with subsequent filing, and the registration already took place, it seems that the "to be" is somehow a slip of the Commission's pen. And, again, article 28b refers to the laws of the State where the branchi s established, while it seems more correct to refer to the registration, instead of establishment.

185 Even if this should be nevertheless guaranteed directly when the business registers interconnection system is used.

186 "Member States shall take the measures required to ensure compulsory disclosure by companie of at least the followiong...": Codified Directive, article 14, italicisation is mine.

187 See also the ICLEG Report's suggestions, p. 20 seqq., also with reference to the single point delivery principle and its impact on the financial markets law.
} 
The second provision, again respectful of the "once-only" principle, deals with the changes that may occur regarding some of the information filed in the register by the company that established the branch. The idea is that, in case of cross-border branches, ${ }^{188}$ the information or documents filed in the register where the company is registered must be communicated, through the register interconnection system, to the register where a branch of such a company is registered. According to proposed article $30 \mathrm{a}$, such information must include changes in:

“(a) the company's name;

(b) the company's registered office;

(c) the company's registration number in the register;

(d) the company's legal form;

(e) the documents and information referred to in points (d) and (f) of Article 14".

This means that most of such information was included, as for initial disclosure, in the list provided by article 30.1 of the Codified Directive.

In this case too, as it happens with the online registration of the branch and with the information flow on the branch's closure, the recipient register must acknowledge the receipt of the information, and the information is to be filed in both of the registers. No further duty of information is pending on the company, the branch, directors or shareholders: the entire information is exchanged between the registers.

Finally, the proposed new subparagraph to article 31 is again a manifestation of the "once-only" principle, as it suggests to hold as disclosed the company's financial documents, according to Codified Directive's article 14(f), also with reference to such company's branches, again by virtue of the business register interconnection system.

\subsection{FURTHER - “HOUSEKEEPING” - PROVISIONS}

Apart from those analyzed so far, in the Proposal there are a few additional provisions that can be said for "housekeeping" purposes, as they are either intended to enhance the performance of existing rules, or to provide norms apparently not very much digital-related, or to repeal articles that were erroneously maintained in the Codified Directive as of its elaboration and publication.

188 Actually, proposed article $28 \mathrm{c}$ does not mention the necessity that such a branch is abroad; nevertheless, the wording, besides common sense, suggests that this is the scope of application of such rule. 


\subsubsection{RULES ON DISQUALIFIED DIRECTORS}

An unprecedented rule in the Proposal deals with the disqualified directors. We can say that this suggestion too is a rather logic follow-up of the importance gained by the business registers interconnection system; equally, we must note that such proposal has fallouts at large exceeding the issue of digitalization itself.

The core idea is that, as the business registers interconnection system allows accessing a series of information previously unimaginable, Member States might use such information also in order to prevent that a person disqualified as director in another Member State can serve as a director for companies registered in their own registers. ${ }^{189}$

The provision deals with disqualification of directors, but also with their ineligibility as directors. ${ }^{190}$ Member States may "refuse the appointment of a person as a director of a company where this person is currently disqualified from acting as a director in another Member State". This is just a possibility for Member States, to be supported by an optional domestic implementation rule, and the knowledge of such "foreign disqualification" comes to the Member States properly through the business registers interconnection system: the information on disqualification must be filed in the register, "in respect of what period any disqualification is in force". ${ }^{191}$ The notion of "director" to the extent of the provision cross-references that laid down in article 14(d) of the Codified Directive.

This proposal leaves some doubts, even if its purpose is clear and can be shared, as aims at an enhancement of the security and reliability throughout the Union.

In spite of being the fallout of what looks like a free option of each Member State, it is not clear at all the extent of obligation proper to the proposed provision. There are two rules that seem to be conflicting about this issue.

On the one hand, Member States are naturally free to provide for domestic grounds of disqualification, ${ }^{192}$ as it usually happens. Such grounds can be and usually are - rather different from one Member State to another, and the domestic bodies (administrative or judicial) entitled to declare the disqualifi-

\footnotetext{
189 Proposed article 13h.3.

190 Proposed article 13h.4.

191 Proposed article 13h.2.

192 Ibidem, and being the verb "may" to be intended as Member States could even avoid to set down causes of disqualification in their national law.
} 
cation differ meaningfully on a Country basis. On the other hand, according to the Proposal, Member States may also provide, as of a company's registration, for "the procedures to verify the appointment of directors taking into account the disqualification of directors by competent authorities of other Member States". 193

The point of the aforementioned provision lays in the meaning of "taking into account". First, it is clear that each Member State is free either to establish such procedure, or not. In the latter case, no issue arises, as this simply prevents such Member State from extending within their borders the consequences of foreign disqualifications: where lacking the provision, the directors of a company lawfully established in that Member State will be free to continue serving as directors even if they had been disqualifies in another Member State. The difficulties of interpretation arise in the former case, and deal with the extent of the "taking into account".

Basically, there are two different ways the Member States could adopt for "taking into account" the foreign disqualification, once that they freely decide to implement the rule in their domestic system. On the one hand, the "taking into account" could be intended as a mere knowledge of a possible foreign disqualification. This enables the use of the interconnection system, allowing it to be aware of the disqualification abroad of a person to be appointed as a director in a domestic company, but with no direct further consequence. However, this situation would not need a specific provision in domestic law: this could be equally achieved simply by mentioning the disqualification of directors in the information to be entered in the interconnected registers. The optional provision under proposed article 13f.4(d) simply would mean that there is an obligation to check the registers for discovering whether the chosen directors have been previously disqualified abroad, or not. This does not seem to be really useful, if the appointment of an "already abroad disqualified director" remains possible with no penalties.

The second interpretation, on the other hand, seems to be much more effective; perhaps too much. The "taking into account" (art. 13f.4(d)) would mean that the knowledge of a foreign disqualification is the necessary condition for the domestic application of the consequences of a foreign disqualification, forbidding the appointment of a director that has been previously disqualified abroad (art. 13h). This means that, once that a Member State adopts domestically both

193 Proposed article 13f.4(d). The national rules shall certainly deal with the identification of who has the duty to check the disqualification of a proposed director, and the penalties for noncompliance. Furthermore, it is clear that, in those systems where a notary is present, such a duty will reasonably played by the notaries; it is not clear at all how such check may take place in the remaining Member States, perhaps leaving the entire issue to the automatized system. 
of the provisions under arts. 13f.4(d) and 13h, ${ }^{194}$ this would trigger the extension not of the grounds, but of the consequences of the disqualification beyond national borders. The disqualification occurred in Member State "B", according to the grounds for disqualification Member State "B" lays down, would have its effects in Member State "A" too, when Member State "A" implements arts. 13f.4(d) and 13h, even if the ground for disqualification occurred in "B" is not a legal ground for disqualification in " $\mathrm{A}$ ".

Furthermore, the wording of art. 13f.4(d) is ambiguous: it is clear that each Member State is free to decide whether taking into account a foreign disqualification, or not. Meanwhile what is not clear is the extent of such "foreign": according to the wording, each Member State seems to be free to take into account what happens in one, more, or all of the other Member States. It is clear that there is not harmonization at all, by this way, as each Member State would be free to choose the foreign system(s) whose effects would be extended, as far as disqualification is concerned, in its own company law. The system could thus turn unequal: the same circumstance could be justified ground for disqualification in a Member State, but not in another; and vice versa. ${ }^{195}$ Once that it occurs in a Member State where the situation is ground for disqualification, this disqualification shall be operative also in those Member States where the situation is not a ground for disqualification. We cannot say that there would be a "cross-border disqualification system": such rules are not material norms, and no system is built up directly by the European lawmakers. On the other hand, there could be a large spread of the effects of foreign disqualifications, even in asymmetric ways. This seems to lead to an even more chaotic system than the current one, and makes the proposed provision rather questionable, if not lacking at all a legal basis among those mentioned in the Proposal - the best suitable seems to be art. 50.2(b) of Treaty on the Functioning of the EU, even if at large forced.

Again, the proposed rule requires to be recorded in the register the persons "currently disqualified from acting as a director". It is not clear whether this list of disqualified people should include only those people disqualified while they were in charge as company's directors; or, as it seems more reasonable, the list includes all those people (Citizens? Residents? Foreigners too?) that

194 From the reconstruction I operated, it should emerge quite clearly that there is no possibility for Member States to implement only art. 13h, without implementing art. 13f.4(d), unless the explicit implementation of the former implies an implicit implementation of the latter; while it is possible the implementation of art. 13.4(d) alone.

195 We could thus have some Member States considering the foreign disqualification, and others refusing it; it should be investigated whether this situation, that is very likely to have an impact on the regulatory competition, could lead to a race to the top or to one to the bottom. 
are in the subjective condition of being ineligible for the office of director of a company. This solution is likely to create a Europe-wide proscription list whose compatibility with Data Protection rules is to be carefully examined.

Finally, the wording of the proposed rules on disqualified directors gives the idea that the check regarding the personal status of the directors to be is to be performed upon registration; ${ }^{196}$ and explicitly such rule is applicable also upon the appointment of a new director, whose possible disqualification abroad is to be verified. ${ }^{197}$

The grounds for a director's disqualification are nevertheless likely to happen, and be subsequently registered in the digital cross-border proscription list, even while the person is already in charge as a director of a company in another Member State than the one where the disqualification was decided. If so, the occurrence of a cause of disqualification for the company's director in Member State "A" would certainly lead to the end of his/her experience as a director of companies registered in Member State "A". It is nonetheless questionable whether the proposed rules allow the same to happen when he/she is a director of a company in Member State "B". The paradox would be that the cross-border disqualification could operate just from the beginning of the office as a director, and not later.

In any case, it should be rather clear that the proposed rule on the disqualification of directors has fallouts largely exceeding the very field of digitalization, and would heavily affect Member States' domestic laws. A "softer" approach based on an attempt of harmonization of grounds and effects or disqualification for a company's directors would perhaps be a more appropriate path.

\subsubsection{DISCLOSURE IN THE REGISTER AND ACCESS TO INFORMATION}

We have already seen that many of the provisions in the Proposal deal with the business registers interconnection system. The Proposal itself can be seen, at least as far as the "once-only" and free cross-border access principles, as a means to enhance the utility of such a tool. In order to do that, however, a few amendments to the norm on disclosure - article 16 of the Codified Directive - were needed; and the Digitalization Proposal suggests some changes accordingly.

\footnotetext{
196 Explicitly the proposed article 13f.4(d) and also 13h.1: "the register where the company is to be registered (...) may request confirmation (...) whether or not the person who is to be appointed as a director (...) is currently disqualified"; italicisation is mine.

197 Proposed article 13h.4.
} 
The current content of article 16 would be split into the proposed articles 16 and 16a. A few of the older provisions would be repealed, and some new would be added, while the pre-existing structure would be substantially maintained, apart from the provisions on the access to disclosed information currently included in article 16.4, which would be translated in proposed article 16a.

Many of the proposed changes deal with terminology, and do not seem to be substantial; for instance, the term "particulars" would be replaced with "information", "whether... or" with "irrespective", and so on. On this basis, we can note that proposed article 16.1 is maintained the same as in the version currently in force, and new paragraphs 2 and 4 would replace, without meaningful amendments, current paragraphs 3 and 6.

The current paragraphs 2 and 7 are missing in the proposed new text, and so the second subparagraph of paragraph 3. In this last case, however, its lack is due to the already analyzed more detailed proposed rules on the online filing of companies and branches. ${ }^{198}$ Finally, the proposed new paragraph 3 amends in a substantial way the current paragraph 5, regarding the means of disclosure; a new paragraph 5 is included in the proposal. As for article 16a, it is a restatement and update of current article 16's paragraph 4, just with a remarkable difference on the certification of electronic copies.

The proposed repeal of paragraph 2 is due ${ }^{199}$ to the fact that a definition of "electronic means" was held as superfluous "since the new proposed rules on online procedures". ${ }^{200}$ Such a conclusion seems to be questionable: it is true that the new article 13a supplies new definitions for many digital-related issues, but none of them deals specifically with "electronic means"; and this wording is nonetheless present many times in the proposed rules. For this reason, even if it is systematically correct to remove the definition from article 16, it seems in any case reasonable to maintain it in the proposal, ${ }^{201}$ for instance integrating the content of article 13a.

The repeal of the current paragraph 7 is to be dealt with along with the amendments proposed to paragraph 5 - paragraph 3 in the proposed new article.

As it is well known, the disclosure and publication system currently in force has two basic pillars: the register for the disclosure itself and the national ga-

\footnotetext{
198 See above, paragraph 5.3.3.

199 According to the explanatory memorandum to the Digitalisation Proposal, p. 13.

200 In the Impact Assessment, p. 14 it is stated that "the current definition [...] is not specific enought and leads to a diverse implementation in the MS".

201 Possibly changing its wording in order to overcome the differences in the implementations by the Member States the Impact Assessment mentions.
} 
zette for the publication as a means of disclosure. We must highlight that, due to the Digitalization Proposal, but also by virtue of the implementation of the BRIS, the role of the registers in the disclosure procedure has been hugely enhanced. At the same time, in spite of the provisions of the Codified Directive suggesting a new digital role for national gazettes, ${ }^{202}$ the publication in such official journals is perceived as largely outdated, and practically ineffective. ${ }^{203}$

For these reasons, the proposed new paragraph 3 aims at modifying the system, by using the registers also as a direct means of disclosure, leaving the Member States free to maintain the national gazette as an additional and optional means of disclosure. In any case, the disclosure is effected by registering documents and information in the register. As an application of the once-only principle, furthermore, even when the Member States choose to maintain the additional publication in the national gazette, ${ }^{204}$ the duty to transmit the information to the gazette for the publication is not on the company's directors any longer, but belongs mandatorily to the national register. By this way, the company only has to register the information once; one more case of implementation of the "once-only" principle.

As the system of disclosure and publication would change so meaningfully, the current paragraph 7 , on the possible discrepancies between what is recorded in the register and what is published in the gazette seemed useless to the lawmaker. Actually, while in the current system the public reliability of the system depends on what is published, and not filed in the register, ${ }^{205}$ the proposed new system disregards at all the publication for the purposes of reliability against third parties, as this is affected by the public availability in the register. ${ }^{206}$ Any possible discrepancy between what is registered and what is published, should a Member State maintain the optional publication in the national gazette, is by a matter of fact resolved in favor of what has been registered. ${ }^{207}$

The proposed rule is a welcome simplification of the disclosure procedure. It seems nevertheless that, in order to be effective, the rule should be coordinated

\footnotetext{
202 See above, chapter 3 for more details.

203 Regarding the different options considered in drafting the Proposal, see the Impact Assessment, p. 49 seqq.

${ }^{204}$ In the proposed new version, there is not the specification regarding the fact that the national gazettes may be kept in electronic form, but nothing seems to prevent such possibility even with the proposed text.

205 Current article 16.7, second subparagraph, Codified Directive.

206 In the same terms the Impact Assessment, p. 51.

207 Besides that, the risk of discrepancies should be minimised by the fact that who sends the information for the publication to the gazette is the register itself.
} 
with the many provisions in the Codified Directive at least dealing with the publication according to the current version of article 16 , for instance those on drafts of merger and division. ${ }^{208}$ And, again, for the sake of the overall system, similar steps should be taken for the Regulations on the EEIG, SE and SCE. ${ }^{209}$

To conclude with the proposed new article 16, the new paragraph 5 supplies a technical detail regarding the electronic format of the data recorded in the register due to a company's or a branch's registration, or subsequent filing. Such data must be stored "in a machine-readable and searchable format or as structured data". This requirement is laid down in order to allow the highest possible degree of automatization in the management of recorded data, taking the full benefit of the register system again with a view to its system of interconnection. ${ }^{210}$

Moving to the article $16 \mathrm{a}$, as already anticipated it is at large a restatement of the current article 16.4, save for a couple of major discrepancies.

The most important one, from a systematic point of view, is the fact that, changing diametrically the current provision, the proposed paragraph 3 lays down the rule that the "Electronic copies supplied to an applicant shall be certified as 'true copies' unless the applicant dispenses with such certification". ${ }^{211}$ This is what currently happens with copies supplied by paper means, ${ }^{212}$ while for the electronic ones the certification is currently supplied upon explicit request. The revolution imagined by the Proposal finds a technical support in the proposed paragraph 4, laying down the rule that the authentication of the extracts coming from the registers must be ensured by means of the trust services the e-IDAS Regulation refers to. By this way, the integrity and certification of data is once again a matter depending on the e-IDAS.

\footnotetext{
${ }^{208}$ Regarding this issue in particular, see above, chapter 3. Moreover, with a strong register-centered system as that imagined by the Proposal, it should be reconsidered also the exemption from the publication laid down in articles 92, 123 and 138.

209 For instance, for EEIG, the Council Regulation (EEC) No 2137/85 of 25 July 1985 on the European Economic Interest Grouping EEIG, (OJ L 199, 31/7/1985), art. 39.1, third sentence, leaves to the Member States the duty to "ensure that the documents and particulars referred to in Article 8 are published in the appropriate official gazette of the Member State in which the grouping has its official address". It is thus possible that in some Member States such obligation impends on directors, and in others on the register.

210 This could also be useful for the purposes of the publication in the national gazette, if any.

211 As also proposed by the ICLEG Report, p. 20.

212 By the way, the proposed article 16a, unlike the current article 16.4, does not consider not-electronic copies at all; this could lead to issues with the certification of true copies of the paper copies - that should be held as anyway possible even in the absence of a specific provision - that would lack any default rule.
} 


\subsubsection{SCOPE OF DISCLOSURE AND FEES FOR INFORMATION}

Along with those already examined, the Proposal introduces amendments in the article 18 of the Codified Directive, and a new wording for article 19.

As for article 18, the suggested provision is, once more, the fallout of the enhanced importance of the registers. The proposed additions aim at making available "documents and information referred to in Article 14 for types of companies other than those listed in Annex II". The meaning of such proposal is not perfectly clear. Perhaps, the goal of such extension is to make available - even for the BRIS purposes ${ }^{213}$ - the information regarding other types of "business organizations", instead of companies, as the Annex II already considers the company type present in each jurisdiction.

As of the proposed article 19, its leading principle is that the cost for information throughout the Union should be reduced. For this reason, the proposed version of this article does not reduce the fees for getting information, which is not possible as they are already not exceeding the pure administrative costs, but widens the scope of information available free of charge - meaning, again, at a fee equal to just the administrative cost. ${ }^{214}$

Besides the information on the name, the legal form, the registered office and the unique registration number (EUID) of the company, it should be available free of charge at least ${ }^{215}$ also the information on:

“(d) details of the company web-site, where applicable;

(e) the legal status of the company, such as when it is closed, struck off the register, wound up, dissolved, economically active or inactive as defined in national law and where available in the national registers;

(f) the object of the company, where it is recorded in the national register;

(g) the number of employees of the company, where this is available in the company's financial statements as required by national law;

(h) the name of any persons currently authorized by the company to represent it in dealing with third parties and in legal proceedings or to take part in the

\footnotetext{
213 See the Whereas 20 of the Preamble.

214 Again, according to the Impact Assessment, p. 51 seqq., the option of a full, free information was explored, but could not be pursued as it was likely to trigger an unbearable lack of resources for the registers.

215 As according to the proposed article 19, last subparagraph, Member States are free to make further information and documents available free of charge. The same option is already present in the current text.
} 
administration, supervision or control of the company, as referred to in Article 14(d);

(i) information on any branches opened by the company in another Member State including the name, registration number, EUID and the Member State where the branch is registered".

To the end of this paper, it is worth highlighting at least the proposed point (d), with reference to the details of company's website. The interpolated clause "where applicable", however, once again witnesses that there is no general obligation for companies to have a website, besides the few already seen above in Chapter $3 .^{216}$

\subsubsection{HOUSEKEEPING'S MEDLEY, IN PARTICULAR PROPOSED ANNEX IIA ON THE SCOPE OF APPLICATION}

Finally, a few remarks on some provisions present in the Proposal and that do not suit with the categories examined so far.

Proposal's article 1.10 suggests amendments to Codified Directive's article 22, allowing that additional access points to the BRIS can be established not just by Member States, but also "by the Commission or other Union institutions, bodies, offices or agencies in order to perform their administrative functions or to comply with provisions of Union law". Once again, we can find in this proposed amendment a way to enhance the effectivity of the BRIS, for purposes going beyond the European Company Law strictly intended.

Subsequent paragraph 11 deals with technical specifications and procedures that are to be changed again in the BRIS.

Paragraph 16 provides for the repeal of the Codified Directive's article 43, due to an arisen lack of legal basis for such provision.

Paragraph 17 proposes an updated wording for Codified Directive's article 161 on Data Protection, due to the approval of Regulation (EU) 2016/679, replacing the Directive 95/46/EC.

Finally, a few words on Annexes.

As for Annexes I and II of the Codified Directive, the Proposal, in its article 1.20 and .21 simply introduces the difference between the private and the public companies established under Swedish Company Law, in order to allow there too the differential application already present in the remaining Member States.

216 See ref. 98 and 104. 
Furthermore, as we have already pointed out, the Proposal aims at introducing an additional Annex IIA, listing the Member States' domestic private company forms only, for the purposes of articles 13,13e, 13g and 162a. The list the Annex IIA offers is rather curious. Dealing with Member States' national company forms, it should include solely company forms already listed in the Annex II of the Codified Directive, "cherry-picking" among them the private types; nevertheless, it does not work properly that way.

Even if in the majority of the cases the proposed Annex IIA provides for a specification where compared with the content of Annex II, ${ }^{217}$ this does not happen always. This is possibly due to a partial overzealousness attitude of the Proposal.

In many cases, in fact, along with the private company types already listed in the Annex II, a few new ones are considered as well. In several cases, they are the simplified versions of the major company types; ${ }^{218}$ in other ones, the single-member versions of the private companies. ${ }^{219}$ In any case, such an approach is wrong from a theoretical point of view, incomplete from a practical one, should someone incorrectly agree on its theoretical foundations, and very much likely to generate issues even for the overall structure of the Codified Directive.

As for the theoretical foundations, both the single member and the simplified versions of the domestic private companies mentioned in the proposed Annex II do not seem to be autonomous company types in their national Company Laws, separated from the general private companies' one. ${ }^{220}$ In spite of the denomination not including the word société, this is true also for the French

\footnotetext{
217 This happens also as far as the Irish and UK's company forms are considered, where the Annex II simply lays down the application of the rules concerned to, generically, "companies incorporated with limited liablity", while the proposed Annex IIA specifies, respectively, "private company limited by shares or by guarantee/designated activity company" and "Private Limited by shares or guarantee". Such a normative tecnique had already been used in the current Annex I to the end to select public companies.

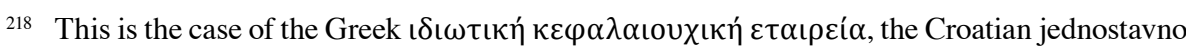
društvo s ograničenom odgovornošć, the Italian società a responsabilità limitata semplificata.

219 So with Belgium (société privée à responsabilité limitée unipersonnelle/Eenpersoons besloten vennootschap met beperkte aansprakelijkheid), France (entreprise unipersonnelle à responsabilité limitée, société par actions simplifiée unipersonnelle), and if I well understand Bulgaria (еднолично дружество с ограничена отговорност).

${ }^{220}$ For instance, with reference to Italian società a responsabilità limitata semplificata, see Bartolacelli, A.: The New Italian Almost Capital-less Private Companies: A Brand New Tile in the Mosaic, European Company and Financial Law Review, 2016, p. 685 seqq.; Id.: L'insostenibile leggerezza dell's.r.l.s., Rivista Orizzonti del diritto commerciale [www.rivistaodc. eu], accessed on 19/08/2018, 2014, 2, p. 4, footnote 7, where more references.
} 
entreprise unipersonnelle à responsabilité limitée, which is to be intended as the single-member version, ab initio, of the société à responsabilité limitée. ${ }^{221}$ For these reasons, it seems at least useless to mention explicitly these company versions, as the rules laid down for private company forms are directly applicable to them, too, for their being already included in the main company type.

Nevertheless, even if to the eyes of the European lawmaker such version should be treated as autonomous company types - an approach that, once again, we do not share at all - it cannot be understood why the Proposal cites some national cases, and "forgets" others, even much more meaningful. In particular, if the simplified forms are to be considered, it makes almost no sense citing Italian S.r.l.s., or the Greek I.K.E., and not the German UG, the Belgian s.à.r.l.-starter, the Danish IVS, or the very recent s.à.r.l.s. of Luxembourg, among the others. ${ }^{22}$ And, as for the single-member companies, due to the former Twelfth Directive, ${ }^{223}$ they are currently present in every Member State, and we cannot understand why only the Belgian, Bulgarian and French versions have been mentioned in the proposed Annex IIA. ${ }^{224}$

Even if these remarks should be already sufficient to question the content of the proposed Annex IIA, it is our belief that it could be even dangerous for the application of the remaining part of the Codified Directive, if approved in the current version. In fact, if we support the statement that the single-member and simplified versions of private limited companies listed in Annex IIA are autonomous company types, as they are not stated in the Annex II, all the provisions applicable to the companies listed in Annex II would not be binding for such company versions. This, at least, as far as the list of Annex II is not updated in order to include them too, even if the Proposal on Digitalization, which would be an appropriate mean as it suggests changes to the Swedish

221 Bartolacelli, A.: Almost Capital-less Companies in Europe: Trends, Variations, Competition, European Company and Financial Law Review, 2017, p. 192 seq. and in particular footnote 25 .

222 A rather complete panorama can be found in Bartolacelli, A.: Almost Capital-less, cit. in the previous ref. 221.

223 Now replaced by Directive 2009/102/EC of the European Parliament and of the Council of 16 September 2009, in the area of Company Law on single-member private limited-liability companies, (OJ L 258, 1/10/2009).

224 Explicitly asked about such issue during the 2018 ECFR Conference in Madrid, on September $28^{\text {th }}, 2018$, a representative of the European Commission replied that it is up to the Member States to inform the European Institutions regarding the domestic legal forms to be included in annexes. Even if it is so, it seems that the Commission, also due to the fact that is currently dealing with issues strictly linked to the concept of company type - such as conversion in its cross-border dimension - should play a strong role in defining clearly the information the Member States are required to provide. 
company forms, does not provide in this sense. Such conclusion is likely to create unjustified differences in the application of domestic private Company Laws, and seems to be avoided as much as possible.

\section{CONCLUSIONS}

The first conclusion we can reach regarding the digitalization in European Company Law is that, as it should be rather clear after the panorama supplied in this paper, it is an ongoing process with roots tracing back to sixteen years ago. Nevertheless, there is no doubt that at least the declared purpose of the Proposal on Digitalization of April 2018 is to be the first comprehensive document on such issue. This goal seems just partially achieved.

The Proposal on Digitalization can be seen as some kind of "finish line" for those provisions aiming at a more enhanced "external digitalization", as it involves the very start-up moment of the company, i.e. its registration. Nonetheless, this deals more with e-government issues than with Company Law strictly intended, and thus it is basically an Administrative Law subject. And that the very recipient of the Proposal are in particular Small and Medium Sized Enterprises, as it has been in all of the latest proposals issued by the Commission, as for instance the SPE and the SUP.

If even it is true that Company rather than Administrative Law are just labels, we must point out that the "private" part of Company Law, the one dealing with the internal structure and functioning of European companies, is not affected in an appreciable way by the Proposal. The Proposal on Digitalization in Company Law, in other words, does not increase by itself the degree of digitalization of the Companies, but just the digitalization of Member States' public sector with reference to Company Law issues.

Although a push towards actions in the field of internal digitalization, with a special focus on the communication between the shareholders and the company, came from the ICLEG Report, and even from the currently existing rules on shareholders' rights in publicly traded companies, the Commission's proposal decided not to deal with such issue at all, concentrating the efforts mainly on business registers. It is possible that Member States would have seen in it an undue intervention of the European institutions in their domestic affairs and therefore would have hardly accepted a strong intervention on that; nevertheless, the Commission did not show an irresistible courage on that. In addition, it is not said that such kind of proposal for internal digitalization should have been necessarily very strong. On the contrary, it even could be based just on the provision of enabling rules for all the companies regarding the use of digitalization tools in the company's day-by-day management and communication 
towards the shareholders/members and third parties. Of course, a simple enabling rule would not have been enough, and should have been accompanied by rules for guaranteeing the right of equivalent information to dissenting subjects. However, this could have been a starting step for a real digitalization of companies throughout Europe.

The second issue is linked to the first one. The Commission's approach to this subject is - as it was in many other unfortunately unsuccessful occasions very focused on the start-up phase of the company. We could say, even, too much focused on that. Clearly, the Commission is interested in the need to remove barriers to the Single Market, and such barriers are very much likely to occur when a company is established. In this sense, the Digitalization Proposal is just a little more than a revival of the $S U P$ proposal, with a broader extent and paying more attention to the role of notaries as of a company's registration.

In any case, the start-up is not the only moment for restrictions to the Single Market. On the contrary, in an actually functioning Single Market, the free choice of the company form, expression of the regulatory competition between the Member States, implies that such a company established abroad for reasons of convenience, can also be managed in its internal corporate governance without needing the physical presence of its members and directors. Surely, the online filing system the Proposal enhances for both companies and branches serves this purpose from an external perspective; an enabling rule imposing the Member States to accept electronic means of participation for every kind of company type would be utmost useful as well. Unfortunately, it seems that the European institutions are much more driven by the "glamour" issue of short time and low cost for establishing a company, rather than the less "sexy" day-by-day management. Possibly, it is a matter of self-promotion of European institutions, along with the real necessity of an opener access to company forms abroad. However, if such facilitation to a company's birth does not evolve into a facilitation of a company's management and evolution, it risks being a kind of cathedral in the desert, whose practical advantage is rather questionable. Something has been moving in this sense with the Proposal on cross-border conversions, mergers and divisions presented in April 2018 too, but such operations are somehow extraordinary as well, while a more comprehensive action in the ordinary management of companies seems to be needed.

Again, the main feature of the Proposal and the cornerstone of the entire digitalization framework is the business register, and the system of interconnection of domestic registers. It is enhanced in its importance by the Proposal, as we have already seen. The Proposal even advocates for a general withdrawal of the double system of disclosure, currently based on the couple disclosure + 
publication, leaving the business register disclosure alone, and abandoning the publication in the national gazettes.

Such an attitude seems to be praised, and is essentially a part of a broader cultural fight in act. On the one hand, the "once-only" principle the Proposal adopts can be mirrored, on the administrative side, by a "single point of information" idea, identifying a unique place the citizens can rely on for retrieving the information regarding the companies. Such a single point of information is, thus, the register, and the national gazette, where present, only has an optional and ancillary function. Furthermore, the national gazette in electronic form facilitates very much the receipt of information from the register, and possibly an automatic publication of the same information in both of the places, minimizing if not excluding at all the risk of discrepancies between the same information disclosed through different means. However, the key point is that the national gazette could even not play any role at all in the disclosure process, in the system the Proposal draws. This means that the Proposal imagines the business register as the only mandatory (and reliable) means of disclosure; the natural consequence of this is that the disclosed information is to be readily and easily accessible to the public. If we look at the experience of the national gazettes, in spite of being the most traditional means of disclosure, we cannot say that they were commonly read by citizens; their traditionally hardcopy structure, in addition, does not facilitate searches at all, nor the creation of a "single-company-archive" of information. The latter feature is, on the contrary, one of the key characters of the business register, once that it is kept in an electronic form. Naturally, the system of interconnection of business registers, together with the unique identifier of registered companies, enhances the possibilities of search, and enables a quick recognition of the entire information linked to a given company. This does not guarantee by itself an easy access to the information and for this reason the Commission decided to establish single portals for facilitating the searches. The idea, in the proposal, to create more access points, managed by European institutions as well, is from this point of view perfectly consistent with such an attitude, and a way to get the most proficiency from the registration system. The cultural fight is, thus, make the citizens to consult the registers much more than they have been doing with the national gazette; the proposed increase of the information available free of charge points right in that direction.

All of the remarks so far make it clear the importance the register acquired to the eyes of European institution, the Commission in particular. The registers' interconnection system is the cherry on the cake of such framework. It should nonetheless be questioned whether such system has not born somehow old. The domestic systems, although complying with similar criteria so to make the interconnection functioning, are nonetheless proprietary ones, and even 
the BRIS is a net of centralized domestic registers: a "double level centralization". The most recent developments in the general field of registration are, on the other hand, focused on the possibility to use the blockchain technology, which would be even more secure, and would not imply the presence of central registers, while authentication authorities could in any case survive and play a role. ${ }^{25}$ This seems to be an issue to look at very attentively in the next future.

Finally, just a word on the company's website. The Proposal does not enhance its role very much; nevertheless, it seems that the possible absence of the national gazette the Proposal advocates for could be replaced by making the information about the company present in the register automatically available in the company's website. From a technical point of view, this should be greatly facilitated by the requirement of having the filed information available "in a machine-readable and searchable format or as structured data", in the words of proposed article 16.5. The company's website could, thus, retrieve the relevant information directly from the register, making it available twice, in the best interest of the citizens, and thus of the market.

\section{LITERATURE}

1. Bartolacelli, A.: Almost Capital-less Companies in Europe: Trends, Variations, Competition, European Company and Financial Law Review, 2017, p. 192

- DOI: https://doi.org/10.1515/ecfr-2017-0007

2. Bartolacelli, A.: L'insostenibile leggerezza dell's.r.l.s., Rivista Orizzonti del diritto commerciale [www.rivistaodc.eu], accessed on 19/08/2018, 2014, 2;

3. Bartolacelli, A.: La Societas Unius Personae (SUP): verso un nuovo modello societario unipersonale europeo?, Le nuove leggi civili commentate, 2016, p. 601;

4. Bartolacelli, A.: The New Italian Almost Capital-less Private Companies: A Brand New Tile in the Mosaic, European Company and Financial Law Review, 2016, p. 685;

- DOI: https://doi.org/10.1515/ecfr-2016-5009

5. Biermeyer, T. and Meyer, M.: European Commission Proposal on Corporate Mobility and Digitalization: Between Enabling (Cross-Border Corporate) Freedom and Fighting the 'Bad Guy', European Company Law, 2018, p. 110;

6. Conac, P.H.: The Societas Unius Personae (SUP): A "Passport” for Job Creation and Growth, European Company and Financial Law Review, 2015, p. 139

- DOI: https://doi.org/10.1515/ecfr-2015-0139

225 An example can be the Italian "Notarchain" system, under elaboration by the notaries: [https://www.notariato.it/it/tags/notarchain], accessed on 30/8/2018. 
7. Dorresteijn A.F.M. et al, European Corporate Law, Alphen aan den Rijn, 2017;

8. Esteban Velasco, G.: La propuesta de Directiva relativa a las sociedades unipersonales de responsabilidad limitada (en especial la Societas Unius Personae), in: Rojo Fernández-Río and Campuzano Laguillo (eds.): Estudios jurídicos en memoria del profesor Emilio Beltrán, Vol. 1, Valencia, 2015, p. 909;

9. Esteban Velasco, G.: La propuesta de Directiva sobre la "Societas unius personae” (sup): las cuestiones más polémicas, El notario del siglo XXI: revista del Colegio Notarial de Madrid, 2015, p. 148;

10. Esteban Velasco, G.: La Propuesta de Directiva sobre la "Societas Unius Personae” (SUP): el nuevo texto del Consejo de 28 de mayo de 2015, Anales de la Academia Matritense del Notariado, 2015, p. 105;

11. Fuentes Naharro, M.: Una primera aproximación al test de solvencia recogido en la propuesta de directiva sobre la Societas Unius Personae (SUP), working paper [http://www.ucm.es/eprints], accessed on 13/08/2018;

12. Grundmann, S.: European Company Law, Cambridge - Antwerp - Portland, 2012;

13. Guidotti, R.: The European Private Company: The Current Situation, German Law Journal, 2012, p. 331

14. Hansen, J.L.: The SUP Proposal: Registration and Capital (Articles 13-17), European Company and Financial Law Review, 2015, p. 177;

- DOI: https://doi.org/10.1515/ecfr-2015-0177

15. Jung, S.: Societas Unius Personae (SUP) - The New Corporate Element in Company Groups, European Business Law Review, 2015, p. 645;

16. Knaier, R.: Digital first, Bedenken second?, GmbH-Rundschau, 2018, 11, p. 560;

17. Lecourt, B.: La Societas Unius Personae: la nouvelle société unipersonnelle à responsabilité limitée proposée par la Commission européenne, Revue des sociétés, 2014, p. 699;

18. Lucini Mateo, A.: El proyecto de Directiva Europea acerca de la Sociedad Limitada Unipersonal, El notario del siglo XXI: revista del Colegio Notarial de Madrid, 2015, 61, p. 54;

19. Lucini Mateo, A.: En torno al Proyecto de Directiva europea sobre la Sociedad Limitada Unipersonal (SUP) presentado por la Comisión Europea el 9 de abril de 2014, La Ley mercantil, 10 (enero), 2015, p. 24;

20. Malberti, C.: The relationship between the Societas Unius Personae proposal and the acquis: Creeping Toward an Abrogation of EU Company Law?, European Company and Financial Law Review, 2015, p. 238;

- DOI: https://doi.org/10.1515/ecfr-2015-0238

21. Ries, P.: Societas Unius Persononae - cui bono?, NZG - Neue Zeitschrift für Gesellschaftsrecht, 2014, p. 569; 
22. Rondinelli, M.: L'armonizzazione nel diritto delle società: evoluzioni e prospettive, in: Pederzini, E. (ed.): Percorsi di diritto societario europeo, Turin, 2016;

23. Schmidt, J.: Der Vorschlag für eine Societas Unius Personae (SUP) - super oder suboptimal?, GmbH-Rundschau, 2014, 9, p. 130;

24. Serra, C.: Societas Unius Personce (SUP) - Um Golem na União Europeia?, Direito das sociedades em revista, 2014, p. 127.

25. Siems, M.: The Societas Unius Personae (SUP): a Trojan Horse?, [siemslegal. blogspot.it/2014/04/the-societas-unius-personae-sup-trojan.htm], accessed on 13/08/2018;

26. Teichmann, C. and Fröhlich, A.: Societas Unius Personae (SUP): Facilitating Cross-Border Establishment, Maastricht journal of European and comparative law, 3, 2014, p. 536;

27. Teichmann, C. and Götz, A.: How to make a Molehill out of a Mountain: The Single-Member Company (SUP) Proposal after Negotiations in the Council, in: Viera González, A.J. and Teichmann, C. (eds.); Private Companies in Europe: the Societas Unius Personae and the Recent Developments in the EU Member States, Cizur Menor, 2016, p. 29;

28. Wuisman, I.: The Societas Unius Personae (SUP), European Company Law, 2015 , p. 40; 